\title{
Operando Insights into CO Oxidation on Cobalt Oxide Catalysts by NAP-XPS, FTIR, and XRD
}

Liliana Lukashuk, ${ }^{\dagger, \perp}$ Nevzat Yigit, ${ }^{\dagger}$ Raffael Rameshan, ${ }^{\ddagger}$ Elisabeth Kolar, ${ }^{\dagger}$ Detre Teschner, ${ }^{\S} \|$

Michael Hävecker, ${ }^{\S, \|}$ Axel Knop-Gericke, ${ }^{\S}$ Robert Schlögl, ${ }^{\S, \|}$ Karin Föttinger, ${ }^{*} \dagger$ † and Günther Rupprechter*,†

${ }^{\dagger}$ Institute of Materials Chemistry, Technische Universität Wien, Getreidemarkt 9/BC/01, Vienna 1060, Austria

${ }^{\ddagger}$ Institute of Physical Chemistry, University of Innsbruck, Innrain 80/82, Innsbruck A-6020, Austria

${ }^{\S}$ Department of Inorganic Chemistry, Fritz-Haber-Institut der Max-Planck-Gesellschaft, Faradayweg 4-6, Berlin 14195, Germany

"Department of Heterogeneous Reactions, Max Planck Institute for Chemical Energy Conversion, Stiftstraße 34-36, Mülheim an der Ruhr 45470, Germany

\section{Supporting Information}

ABSTRACT: Cobalt oxide $\mathrm{Co}_{3} \mathrm{O}_{4}$ has recently emerged as promising, noble metal-free catalyst for oxidation reactions but a better understanding of the active catalyst under working conditions is required for further development and potential commercialization. An operando approach has been applied, combining near ambient (atmospheric) pressure X-ray photoelectron spectroscopy (NAP-XPS), Fourier transform infrared spectroscopy (FTIR), or X-ray diffraction (XRD) with simultaneous catalytic tests of $\mathrm{CO}$ oxidation on $\mathrm{Co}_{3} \mathrm{O}_{4}$, enabling one to monitor surface and bulk states under various reaction conditions (steady-state and dynamic conditions

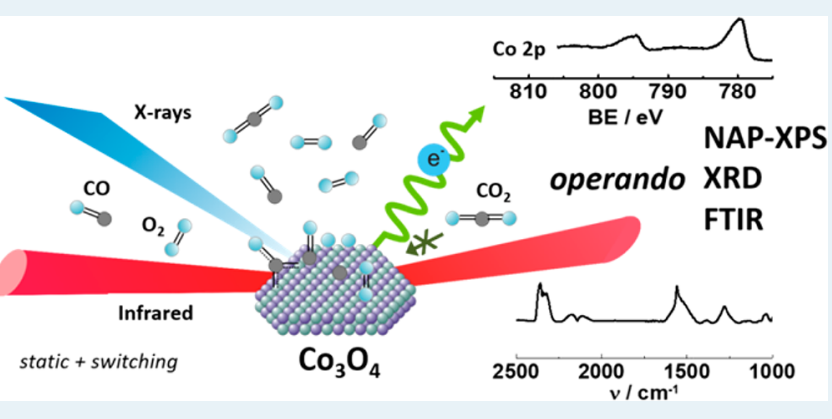
switching between $\mathrm{CO}$ and $\mathrm{O}_{2}$ ). On the basis of the surface-specific chemical information a complex network of different reaction pathways unfolded: Mars-van-Krevelen ( $\mathrm{MvK}), \mathrm{CO}$ dissociation followed by carbon oxidation, and formation of carbonates. A possible Langmuir-Hinshelwood ( $\mathrm{LH}$ ) pathway cannot be excluded because of the good activity when no oxygen vacancies were detected. The combined NAP-XPS/FTIR results are in line with a MvK mechanism above $100{ }^{\circ} \mathrm{C}$, involving the $\mathrm{Co}^{3+} / \mathrm{Co}^{2+}$ redox couple and oxygen vacancy formation. Under steady state, the $\mathrm{Co}_{3} \mathrm{O}_{4}$ surface appeared oxidized and the amount of reduced $\mathrm{Co}^{2+}$ species at/near the surface remained low up to $200{ }^{\circ} \mathrm{C}$. Only in pure CO, about $15 \%$ of surface reduction were detected, suggesting that the active sites are a minority species. The operando spectroscopic studies also revealed additional reaction pathways: $\mathrm{CO}$ dissociation followed by carbon reoxidation and carbonate formation and its decomposition. However, due to their thermal stability in various atmospheres, the carbonates are rather spectators and also $\mathrm{CO}$ dissociation seems a minor route. This study thus highlights the benefits of combining operando surface sensitive techniques to gain insight into catalytically active surfaces.

KEYWORDS: $\mathrm{CO}$ oxidation, $\mathrm{Co}_{3} \mathrm{O}_{4}$, operando, NAP-XPS, FTIR, XRD, surface spectroscopy

\section{INTRODUCTION}

Controlling automotive emissions during an engine's cold start is an unresolved issue, resulting from the strong $\mathrm{CO}$ adsorption on noble metals, poisoning the catalyst at low temperature $\left(<200{ }^{\circ} \mathrm{C}\right) .^{1,2}$ Due to their low-temperature CO oxidation ability, transition metal oxides, ${ }^{3}$ especially cobalt oxide, are promising. ${ }^{4,5}$ Despite intensive studies, the nature of the active sites of cobalt oxide catalysts as well as exact reaction mechanisms are still debated and contradicting results concerning the role of $\mathrm{Co}^{3+} / \mathrm{Co}^{2+}$, of different oxygen species, oxygen vacancies, and carbonates were reported.

The active sites are often attributed to the abundance of specific cobalt cations. In 2009, Xie et al. reported that $\mathrm{Co}_{3} \mathrm{O}_{4}$ nanorods, predominately exposing (110) planes and enriched in $\mathrm{Co}^{3+}$ cations, exhibit very high activity for low-temperature
$\mathrm{CO}$ oxidation. The high catalytic activity was ascribed to $\mathrm{Co}^{3+}$ cations, ${ }^{5}$ but no spectroscopic evidence was given. Two years later the same group reported that $\mathrm{Co}_{3} \mathrm{O}_{4}$ nanosheets with (111) planes, enriched in $\mathrm{Co}^{2+}$ cations, were the most active among nanorods, nanocubes, and nanoparticles, ${ }^{6}$ contrasting with the previous report. Jia et al. observed that a $\mathrm{Co}_{3} \mathrm{O}_{4}-\mathrm{SiO}_{2}$ nanocomposite catalyst, without ordered planes, but enriched in $\mathrm{Co}^{2+}$, exhibited very high activity at low temperature. ${ }^{4}$ Recently, it was reported that $\mathrm{CoO}$ with octahedrally coordinated $\mathrm{Co}^{2+}$ had unexpectedly high activity due to the ease of surface oxidation of $\mathrm{Co}^{2+}$ to $\mathrm{Co}^{3+}$. Nevertheless, all

Received: March 29, 2018

Revised: August 2, 2018

Published: August 7, 2018 
conclusions were primarily based on catalytic studies and no direct spectroscopic evidence of the active surface oxidation state was provided.

A recent study by Iablokov et al. using different particle sizes $(2$ to $10 \mathrm{~nm}$ ) showed a maximum rate between 5 and $8 \mathrm{~nm}$. This was explained by a higher concentration of $\mathrm{Co}^{3+} 3 \mathrm{~d}$ states, as revealed by XPS. ${ }^{8}$ Ding et al. reported an enhanced activity of flower-like $\mathrm{Co}_{3} \mathrm{O}_{4}$ with an increased number of surface $\mathrm{Co}^{3+} \cdot 9$ All findings illustrate that there are still open questions concerning the nature of active sites, i.e., the abundance of $\mathrm{Co}^{3+} / \mathrm{Co}^{2+}$ and $\mathrm{Co}_{3} \mathrm{O}_{4} / \mathrm{CoO}$.

With respect to the reaction mechanism, it was suggested that $\mathrm{CO}$ adsorbs to $\mathrm{Co}^{3+}$ cations, followed by abstracting surface lattice oxygen coordinated to three $\mathrm{Co}^{3+}$ cations, with the oxygen vacancy later replenished by gas phase oxygen (Mars-van-Krevelen mechanism). ${ }^{5}$ Studying the effect of pretreatment conditions, $\mathrm{Yu}$ et al. proposed a reaction between a molecularly adsorbed $\mathrm{CO}$ and molecularly adsorbed $\mathrm{O}-\mathrm{O}$ peroxo species, but without spectroscopic evidence. ${ }^{10}$ However, Jia et al. did not detect peroxo $\mathrm{O}-\mathrm{O}$ species by in situ Raman spectroscopy. ${ }^{4}$ In an in situ IR study, Pollard et al. ${ }^{11}$ suggested that $\mathrm{CO}$ adsorbed on $\mathrm{Co}^{2+}$ sites reacted with an oxygen atom bonded to a neighboring $\mathrm{Co}^{3+}$ cation, and the oxygen vacancy was replenished by oxygen from the gas phase. In his early work on the $\mathrm{CO}$ oxidation mechanism, Jansson et al. had already proven lattice oxygen extraction using isotopes, i.e., the redox Mars-van-Krevelen mechanism. ${ }^{12-14} \mathrm{He}$ also found that $\mathrm{CO}$ disproportionation takes place during $\mathrm{CO}$ oxidation. Mechanistic insights were also gained from reaction orders. The study of Perti et al. on $\mathrm{CO}$ oxidation kinetics on $\mathrm{Co}_{3} \mathrm{O}_{4}-\mathrm{Al}_{2} \mathrm{O}_{3}$ revealed reaction orders of $\mathrm{CO}$ and $\mathrm{O}_{2}$ being 0 and 0.42 , respectively ${ }^{15-17}$ and their study suggested two competitive mechanisms: reaction of $\mathrm{CO}$ with adsorbed oxygen (Langmuir-Hinshelwood LH) and with lattice oxygen (MvK). ${ }^{15-17}$

The CO oxidation mechanism on cobalt oxide has also been examined by theoretical work, ${ }^{18-21}$ also showing divergences. For example, Jiang et al. suggested a MvK mechanism for $\mathrm{Co}_{3} \mathrm{O}_{4}$ (110). ${ }^{21}$ Pang et al. proposed two scenarios: direct reaction of $\mathrm{CO}$ with surface lattice oxygen atoms $(\mathrm{MvK})$ but also direct reaction of preadsorbed molecular $\mathrm{O}_{2}$ with molecular CO from the gas phase. ${ }^{20,22}$

A better understanding of $\mathrm{CO}$ oxidation on cobalt oxide would clearly benefit from an evaluation of the surface oxidation state of the active catalyst, as well as of the surface species present. Applying operando (in situ) techniques for studying the catalyst surface under reaction conditions may enable to reveal the reaction network, which is required for setting up a mikrokinetic model that could eventually explain the macroscopic kinetics. ${ }^{23-25}$ The importance of surface composition changes of a cobalt oxide model catalyst during methanol oxidation was, e.g., revealed by operando near atmospheric pressure X-ray photoelectron spectroscopy (NAP$\mathrm{XPS}) .{ }^{26}$ The goal of the current study was to improve the understanding of the reaction pathways occurring during $\mathrm{CO}$ oxidation on $\mathrm{Co}_{3} \mathrm{O}_{4}$. Thus, NAP-XPS and Fourier transform infrared (FTIR) spectroscopy monitoring the surface changes and surface species were applied with simultaneous catalytic activity tests by gas chromatography (GC) or mass spectroscopy (MS). Experiments were performed under steady-state conditions $\left(\mathrm{CO}+\mathrm{O}_{2}\right)$, in $\mathrm{CO}$ atmosphere, and upon switching between $\mathrm{CO}$ and $\mathrm{O}_{2}$. In addition, the effect of pretreatment conditions on catalyst structure and activity was examined by operando XRD/MS. Altogether, the operando studies provided new insight into the active catalyst surface, several possible reaction pathways, and the presence and stability of surface species.

\section{EXPERIMENTAL SECTION}

2.1. Catalyst. $\mathrm{Co}_{3} \mathrm{O}_{4}$ was used as received from Fluka (purity $99.5 \%$ ). The average crystallite size of $\mathrm{Co}_{3} \mathrm{O}_{4}$ determined by X-ray diffraction was $28 \mathrm{~nm}$, the BET specific surface area was $38 \mathrm{~m}^{2} \mathrm{~g}^{-1}$. According to TEM measurements, the material was composed of nanospheres of 20 to $50 \mathrm{~nm}$ in size. A detailed catalyst characterization was reported previously. $^{27}$

2.2. Catalytic CO Oxidation. CO oxidation was performed in a continuous-flow fixed-bed quartz reactor under atmospheric pressure. The sample (ca. $20 \mathrm{mg}$, mixed with $100 \mathrm{mg}$ quartz powder to avoid mass and heat transfer limitations) was loaded into the reactor and pretreated with synthetic air at $400{ }^{\circ} \mathrm{C}$ for $30 \mathrm{~min}\left(50 \mathrm{~mL} \mathrm{~min}^{-1}\right.$, heating rate of $10{ }^{\circ} \mathrm{C} \mathrm{min}^{-1}$, standard pretreatment procedure). For studying the effect of pretreatment conditions, oxidation at $400{ }^{\circ} \mathrm{C}$ in synthetic air was followed by reduction at $100{ }^{\circ} \mathrm{C}$, $200{ }^{\circ} \mathrm{C}, 300{ }^{\circ} \mathrm{C}$, or $400{ }^{\circ} \mathrm{C}$ in $5 \mathrm{vol} \% \mathrm{H}_{2}$ in $\mathrm{N}_{2}$. After cooling to $30^{\circ} \mathrm{C}$, temperature-dependent $\mathrm{CO}$ oxidation was performed either with $5 \mathrm{vol} \% \mathrm{CO}$ and $10 \mathrm{vol} \% \mathrm{O}_{2}$ in $\mathrm{He}$ or 5 vol \% CO and $2.5 \mathrm{vol} \% \mathrm{O}_{2}$ in He. The total flow rate was $50 \mathrm{~mL} \mathrm{~min}^{-1}$, and the heating rate was $2{ }^{\circ} \mathrm{C} \min ^{-1}$. The catalysts rapidly deactivate at room temperature (RT), why rather higher reaction temperatures were examined. The concentrations of $\mathrm{CO}$ and $\mathrm{CO}_{2}$ in the outlet stream were monitored by gas chromatography (GC) using a HP-PLOT $\mathrm{Q}$ column and a flame-ionization detector (FID) with a methanizer.

2.3. Operando XRD Measurements. Operando XRD experiments were performed on a laboratory diffractometer (XPERT III: PANalytical XPert Pro MPD) using $\mathrm{Cu}-\mathrm{K} \alpha$ radiation (1.54 $\AA$ ) operating in the Bragg-Brentano reflection geometry. The diffractometer is equipped with an Anton Paar XRK 900 high-temperature gas cell. In situ diffraction patterns were recorded in the scanning range from $25^{\circ}$ to $70^{\circ}(2 \theta)$ using a step scan mode with steps of $0.05^{\circ}(2 \theta)$ and a time per step of $2 \mathrm{~s}$. XRD data were analyzed with the HighScore Plus program.

The inlet of the Anton Paar XRK 900 high-temperature gas cell is connected to a gas manifold system with calibrated mass flow controllers; the outlet of the cell is connected to a quadrupole mass spectrometer (QMS) (PrismaPlus QMG 220, Pfeiffer Vacuum, SEM detector). The $\mathrm{Co}_{3} \mathrm{O}_{4}$ (ca. $20 \mathrm{mg}$ ) was placed into a sample holder, inserted into the cell and pretreated in synthetic air at $400{ }^{\circ} \mathrm{C}(30 \mathrm{~min})$. Afterward, the reaction mixture of 5 vol \% CO, 10 vol $\% \mathrm{O}_{2}$, and 85 vol \% $\mathrm{He}$ was introduced and $\mathrm{XRD}$ patterns were recorded at room temperature (RT), $100{ }^{\circ} \mathrm{C}, 150{ }^{\circ} \mathrm{C}, 200{ }^{\circ} \mathrm{C}$, and $250{ }^{\circ} \mathrm{C}$. The same experiment was done after pretreatment in synthetic air at $400{ }^{\circ} \mathrm{C}$ followed by reduction in 5 vol $\% \mathrm{H}_{2}$ in $\mathrm{He}$ at $400{ }^{\circ} \mathrm{C}$ (30 min). For in situ $\mathrm{H}_{2}$-temperature-programmed reduction, the samples were pretreated in synthetic air at $400{ }^{\circ} \mathrm{C}(30$ $\min$ ), then cooled to RT, purged with $\mathrm{He}$, and then 5 vol $\% \mathrm{H}_{2}$ in He was introduced. XRD patterns were recorded at RT, 100 ${ }^{\circ} \mathrm{C}, 200{ }^{\circ} \mathrm{C}, 300{ }^{\circ} \mathrm{C}$, and $400{ }^{\circ} \mathrm{C}$. All experiments were performed at atmospheric pressure with a total flow of $50 \mathrm{~mL}$ $\min ^{-1}$.

2.4. Operando NAP-XPS Measurements. Operando near ambient (atmospheric) pressure X-ray photoelectron 

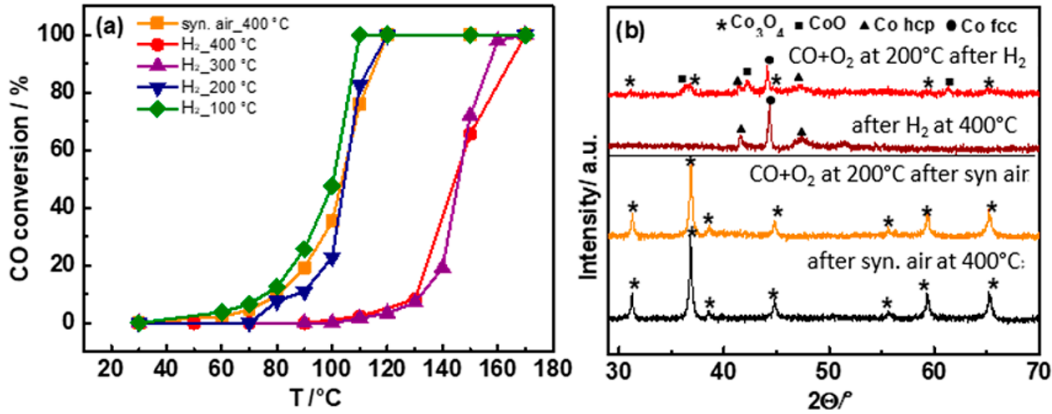

Figure 1. (a) Temperature-dependence of the $\mathrm{CO}$ oxidation activity for a reaction mixture of $5 \mathrm{vol} \% \mathrm{CO}, 10 \mathrm{vol} \% \mathrm{O}_{2}$, and 85 vol \% $\mathrm{He}$ (total flow $50 \mathrm{~mL} \mathrm{~min}^{-1}$ ) for differently pretreated $\mathrm{Co}_{3} \mathrm{O}_{4}$; (b) operando XRD during $\mathrm{CO}$ oxidation at $200{ }^{\circ} \mathrm{C}$ after oxidation pretreatment of $\mathrm{Co}_{3} \mathrm{O}_{4}$ at 400 ${ }^{\circ} \mathrm{C}$ in synthetic air and after reduction of preoxidized $\mathrm{Co}_{3} \mathrm{O}_{4}$ in 5 vol $\% \mathrm{H}_{2}$ at $400{ }^{\circ} \mathrm{C}$. The XRD patterns before starting the reaction are included for comparison.

spectroscopy (NAP-XPS) was performed at the ISISS beamline at the synchrotron radiation facility BESSY II of the Helmholtz-Zentrum Berlin, Germany. The setup consisted of a reaction cell attached to a set of differentially pumped electrostatic lenses and a separately pumped analyzer (Phoibos 150 Plus, SPECS GmbH), as described elsewhere. ${ }^{28}$ Typically, the powder sample (ca. $30 \mathrm{mg}$ ) was pressed into a tantalum grid (to minimize potential charging effects) together with a Ktype thermocouple, fixed to a sapphire sample holder and mounted inside the XPS reaction cell in front of the first aperture of the differentially pumped electrostatic lens system. The heating of the samples was done from the back using an infrared laser. Before the catalytic experiments, the sample was pretreated in the XPS reaction cell by oxidation $\left(0.5 \mathrm{mbar} \mathrm{O}_{2}\right.$ at $400{ }^{\circ} \mathrm{C}$ ) until all residual surface carbon and carbonates disappeared. After cooling the sample to RT, the $\mathrm{CO}+\mathrm{O}_{2}$ reaction mixture (1:2 ratio at $0.5 \mathrm{mbar}$ ) was introduced with the partial pressure of the gases controlled by calibrated mass flow controllers, and the photoemission spectra were recorded. Then, the sample was heated to $100{ }^{\circ} \mathrm{C}, 150{ }^{\circ} \mathrm{C}$, and $200{ }^{\circ} \mathrm{C}$ with a heating rate of $5{ }^{\circ} \mathrm{C} \mathrm{min}^{-1}$, and photoemission spectra were again acquired at these temperatures. For $\mathrm{CO}$ vs $\mathrm{O}_{2}$ switching experiments, $\mathrm{CO}(0.15 \mathrm{mbar})$ was introduced at RT and photoemission spectra were recorded for $\sim 30 \mathrm{~min}$, then the atmosphere was changed to $\mathrm{O}_{2}(0.15 \mathrm{mbar})$, again collecting spectra for $\sim 30 \mathrm{~min}$. Then, $\mathrm{Co}_{3} \mathrm{O}_{4}$ was heated in $\mathrm{O}_{2}$ to the next temperature and the procedure was repeated. Such experiments were performed at RT, 100, 150, and 200 ${ }^{\circ} \mathrm{C}$. To ensure surface sensitivity, the Co $2 \mathrm{p}$ and $\mathrm{C} 1 \mathrm{~s}$ core-level regions were recorded using selected photon energies that resulted in photoelectrons with $200 \mathrm{eV}$ kinetic energy and a $\sim 0.6 \mathrm{~nm}$ inelastic mean free path. The gas phase composition was monitored online by an electron impact quadrupole mass spectrometer, which was connected to the XPS cell via a gas dosing valve.

XPS spectra were analyzed using the CasaXPS package. All binding energies $(\mathrm{BE})$ were calibrated using the second-order $\mathrm{O} 1 \mathrm{~s}$ peak. The accuracy of the BE calibration was estimated to be around $0.05 \mathrm{eV}$. A Shirley-type function was used to remove the background arising from energy loss for Co $2 p$, and either a Shirley- or a linear-type function was used in the case of $\mathrm{C} 1 \mathrm{~s}$. The extracted spectra were then fitted with a combined Gaussian and Lorentzian line profile. The peak positions of Co $2 \mathrm{p}$ and $\mathrm{C} 1 \mathrm{~s}$, full width at half-maximum (fwhm), and constraints are presented in Tables S1 and S2 (Supporting Information, SI).
2.5. Operando FTIR Measurements. Operando FTIR studies were carried out in transmission mode using a Bruker Vertex 70 spectrometer (liquid $\mathrm{N}_{2}$-cooled MCT detector, resolution of $4 \mathrm{~cm}^{-1}$ ) in a stainless steel transmission flow cell equipped with $\mathrm{CaF}_{2}$ windows. The inlet of the cell was connected to a gas manifold system with calibrated mass flow controllers. The sample (ca. 4-5 mg) was pressed into a pellet, which consisted of a thin catalyst layer supported on a $\mathrm{KBr}$ pellet, and placed in a small cylindrical stainless steel sample holder equipped with a ring-shaped furnace and a type- $K$ thermocouple. All infrared spectra were collected in the 4000$900 \mathrm{~cm}^{-1}$ range by averaging 256 scans to achieve good signalto-noise ratio. A spectrum of the empty sample holder recorded in $\mathrm{He}$ was used for background subtraction for all spectra, which were evaluated with the OPUS 4.0 software. During operando FTIR measurements catalytic CO oxidation was simultaneously monitored by gas chromatography (Figure S5).

Before each experiment, the catalyst was pretreated in synthetic air $\left(50 \mathrm{~mL} \mathrm{~min}^{-1}\right)$ at $400{ }^{\circ} \mathrm{C}$ for $30 \mathrm{~min}$ (heating rate $10{ }^{\circ} \mathrm{C} \mathrm{min}{ }^{-1}$ ), cooled to $30{ }^{\circ} \mathrm{C}$ under a flow of synthetic air, and purged with $\mathrm{He}$ for $10 \mathrm{~min}$.

CO Oxidation. the reaction mixtures, (i) 5 vol \% CO, 10 vol $\% \mathrm{O}_{2}$ in $\mathrm{He}$; (ii) 5 vol \% CO, 5 vol \% $\mathrm{O}_{2}$ in He; or (iii) 5 vol \% $\mathrm{CO}, 2.5$ vol $\% \mathrm{O}_{2}$ in $\mathrm{He}$ were passed through the cell at $25 \mathrm{~mL}$ $\mathrm{min}^{-1}$, and temperature-dependent spectra were recorded while heating to $250{ }^{\circ} \mathrm{C}$ with a heating rate of $2{ }^{\circ} \mathrm{C} \mathrm{min}-1$.

CO-Temperature-Programmed Reduction Followed by Heating in $\mathrm{O}_{2}$ or He. Five vol \% CO in $\mathrm{He}\left(25 \mathrm{~mL} \mathrm{~min}{ }^{-1}\right)$ was continuously introduced to the cell and temperaturedependent spectra were recorded while heating to $250{ }^{\circ} \mathrm{C}$. Then, the sample was cooled to room temperature and temperature-dependent spectra were recorded during heating to $200{ }^{\circ} \mathrm{C}$ in 5 vol $\% \mathrm{O}_{2}$ in $\mathrm{He}$ or in pure $\mathrm{He}$.

$\mathrm{CO}$ vs $\mathrm{O}_{2}$ Switching Experiments. $\mathrm{CO}$ ( $5 \mathrm{vol} \% \mathrm{CO}$ in $\mathrm{He}$ ) was introduced and five IR spectra were consecutively recorded within $10 \mathrm{~min}$, then the atmosphere was changed to $\mathrm{O}_{2}\left(5 \mathrm{vol} \% \mathrm{O}_{2}\right.$ in $\left.\mathrm{He}\right)$ again collecting five IR spectra within $10 \mathrm{~min}$. Then, $\mathrm{Co}_{3} \mathrm{O}_{4}$ was heated in $\mathrm{O}_{2}$ to the next temperature and the procedure was repeated. Such experiments were performed at RT, $100{ }^{\circ} \mathrm{C}, 150{ }^{\circ} \mathrm{C}, 200{ }^{\circ} \mathrm{C}$, and $250{ }^{\circ} \mathrm{C}$.

$\mathrm{CO}_{2}$ Adsorption. Five vol $\% \mathrm{CO}_{2}$ in $\mathrm{He}\left(25 \mathrm{~mL} \mathrm{~min}^{-1}\right)$ was continuously passed through the cell and temperaturedependent spectra were recorded while heating to $200{ }^{\circ} \mathrm{C}$. 
Table 1. CO Conversion for a Reaction Mixture of 5 vol.\% CO, 10 vol.\% $\mathrm{O}_{2}$, and 85 vol.\% He (total flow $50 \mathrm{~mL} \mathrm{~min}^{-1}, 20 \mathrm{mg}$ Catalyst) for $\mathrm{Co}_{3} \mathrm{O}_{4}$ Pretreated in Synthetic Air $\left(400{ }^{\circ} \mathrm{C}\right)$ or in Synthetic Air $\left(400{ }^{\circ} \mathrm{C}\right)$ Followed by Hydrogen at the Indicated Temperatures

$\begin{array}{lc}\text { pretreatment } & T_{10 \%}\left({ }^{\circ} \mathrm{C}\right)^{a} \\ \text { Syn_air_400 }{ }^{\circ} \mathrm{C} & 79 \\ +H_{2} 100{ }^{\circ} \mathrm{C} & 76 \\ +\mathrm{H}_{2} 200{ }^{\circ} \mathrm{C} & 88 \\ +\mathrm{H}_{2} \text { 300 } & { }^{\circ} \mathrm{C} \\ +\mathrm{H}_{2} 400{ }^{\circ} \mathrm{C} & 132 \\ \end{array}$

$\begin{array}{cc}T_{50 \%}\left({ }^{\circ} \mathrm{C}\right)^{b} & T_{90 \%}\left({ }^{\circ} \mathrm{C}\right)^{c} \\ 104 & 115 \\ 101 & 108 \\ 105 & 114 \\ 146 & 157 \\ 145 & 164\end{array}$

$r_{90}{ }^{\circ} \mathrm{C}(\mathrm{mol} / \mathrm{s} \cdot \mathrm{g})^{d}$
$1.64 \times 10^{-5}$
$2.18 \times 10^{-5}$
$9.37 \times 10^{-6}$
n.a.
n.a.

$\mathrm{TOF}_{90}{ }^{\circ} \mathrm{C}\left(\mathrm{s}^{-1}\right)^{e}$
$1.9-3.8 \times 10^{-2}$
$2.6-5.2 \times 10^{-2}$
$1.1-2.2 \times 10^{-2}$
n.a.
n.a.

${ }^{a}$ Reaction temperature for $10 \% \mathrm{CO}$ conversion. ${ }^{b}$ Reaction temperature for $50 \% \mathrm{CO}$ conversion; ${ }^{c}$ Reaction temperature for $90 \% \mathrm{CO}$ conversion. ${ }^{d}$ Reaction rate of $\mathrm{CO}$ oxidation at $90{ }^{\circ} \mathrm{C}$ per gram of a catalyst. ${ }^{e}$ Turnover frequency of the $\mathrm{Co}^{3+}$ sites at $90{ }^{\circ} \mathrm{C}$. This estimation is based on the procedure suggested by Xie et al. for nanoparticles of similar mean size and shape, assuming $5-10 \%$ of $\mathrm{Co}^{3+}$ in surface defects as active sites. ${ }^{5}$
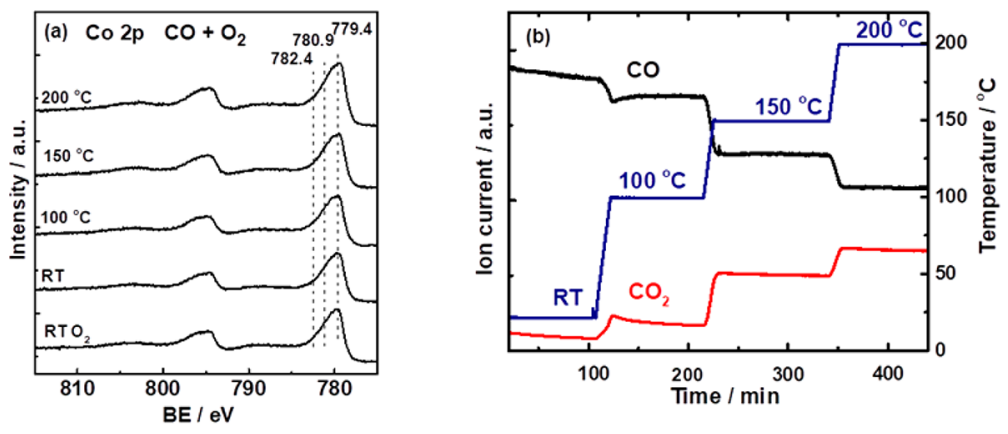

(d)

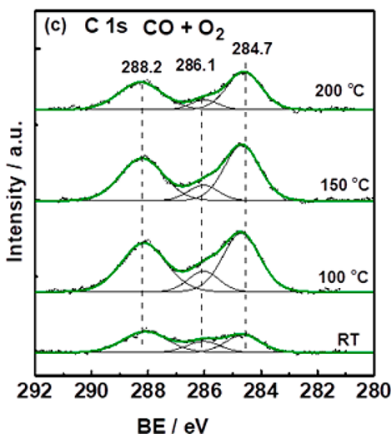

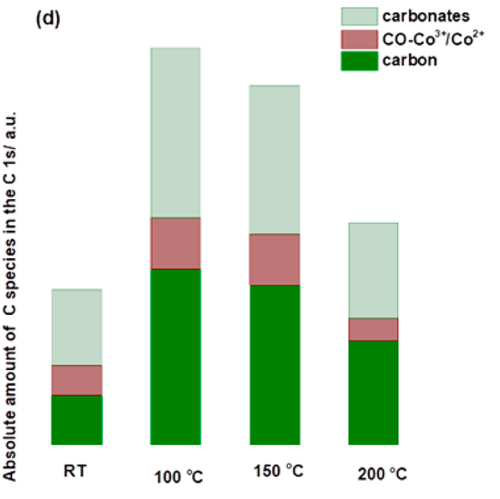

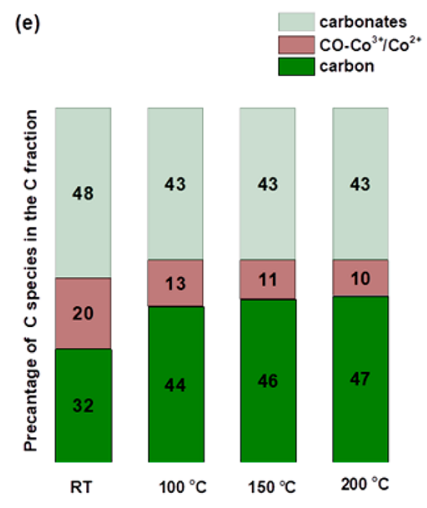

Figure 2. Operando NAP-XPS during CO oxidation on $\mathrm{Co}_{3} \mathrm{O}_{4}$ from RT to $200{ }^{\circ} \mathrm{C}\left(0.15 \mathrm{mbar} \mathrm{CO}\right.$ and $\left.0.3 \mathrm{mbar} \mathrm{O}_{2}\right):(\mathrm{a})$ the $\mathrm{Co} 2 \mathrm{p}$ region $(h \nu=$ $1015 \mathrm{eV}, \mathrm{KE}=200 \mathrm{eV})$; (b) MS catalytic data recorded during NAP-XPS; (c) the C 1s region $(h \nu=465 \mathrm{eV}, \mathrm{KE}=200 \mathrm{eV})$; $(\mathrm{d})$ the absolute amount of carbon species; and (e) the relative ratio between carbon species, both calculated from a linear peak fit.

\section{RESULTS}

3.1. Operando XRD under Steady State Conditions: Influence of Pretreatment on CO Oxidation Activity. The $\mathrm{CO}$ oxidation activity strongly depended on the $\mathrm{CO} / \mathrm{O}_{2}$ ratio (Figure $S 1$; as reported previously), why a $1: 2$ ratio was used for most experiments. To examine the influence of the (bulk) cobalt oxidation state, the $\mathrm{Co}_{3} \mathrm{O}_{4}$ catalyst was pretreated in different ways: by oxidation in synthetic air at $400{ }^{\circ} \mathrm{C}$; or by oxidation at $400{ }^{\circ} \mathrm{C}$ followed by reduction in 5 vol $\% \mathrm{H}_{2}$ in $\mathrm{N}_{2}$ at $100{ }^{\circ} \mathrm{C}, 200{ }^{\circ} \mathrm{C}, 300{ }^{\circ} \mathrm{C}$, and $400{ }^{\circ} \mathrm{C}$. After pretreatment, $\mathrm{CO}$ oxidation was carried out in $5 \mathrm{vol} \% \mathrm{CO}$ and 10 vol $\% \mathrm{O}_{2}$ in $\mathrm{He}$. The temperature-dependent $\mathrm{CO}$ conversion for differently pretreated $\mathrm{Co}_{3} \mathrm{O}_{4}$ is presented in Figure $1 \mathrm{a}$ and summarized in Table $1 . \mathrm{Co}_{3} \mathrm{O}_{4}$ pretreated in synthetic air or in synthetic air $/ \mathrm{H}_{2}\left(100{ }^{\circ} \mathrm{C}\right.$ or $\left.200{ }^{\circ} \mathrm{C}\right)$ was active already at $\sim 80{ }^{\circ} \mathrm{C}$, reaching $100 \% \mathrm{CO}$ conversion at $\sim 110-120^{\circ} \mathrm{C}$ (apparent activation energy around $70 \mathrm{~kJ} / \mathrm{mol}$ ). In contrast, for preoxidized $\mathrm{Co}_{3} \mathrm{O}_{4}$ reduced in $\mathrm{H}_{2}$ at $300{ }^{\circ} \mathrm{C}$ or $400{ }^{\circ} \mathrm{C}$, CO conversion started at higher temperature $(\sim 120$
${ }^{\circ} \mathrm{C}$ ) and reached $100 \%$ at $160{ }^{\circ} \mathrm{C}$ and $170{ }^{\circ} \mathrm{C}$, respectively. This is accompanied by an increase in apparent activation energy to around $110 \mathrm{~kJ} / \mathrm{mol}$, suggesting a different ratedetermining step and different active sites (Figure S2).

Operando XRD upon $\mathrm{CO}$ oxidation on $\mathrm{Co}_{3} \mathrm{O}_{4}$ pretreated in synthetic air and in synthetic air followed by 5 vol \% $\mathrm{H}_{2}$ at 400 ${ }^{\circ} \mathrm{C}$ are shown in Figure $1 \mathrm{~b}$ for $200{ }^{\circ} \mathrm{C}$, with more details in Figure S2. After standard preoxidation, $\mathrm{Co}_{3} \mathrm{O}_{4}$ remained $\mathrm{Co}_{3} \mathrm{O}_{4}$ at all reaction temperatures (Figure $\mathrm{S} 2 \mathrm{a}$ ), in agreement with the in situ XRD study of Jansson et al. ${ }^{14}$ Although the bulk structure of $\mathrm{Co}_{3} \mathrm{O}_{4}$ does not undergo structural changes during $\mathrm{CO}$ oxidation, the topmost surface layers could still be affected, as discussed below.

The low catalytic activity after reduction at $300{ }^{\circ} \mathrm{C}$ or 400 ${ }^{\circ} \mathrm{C}$ is due to the reduction of $\mathrm{Co}_{3} \mathrm{O}_{4}$ to metallic cobalt, as revealed by in situ XRD (Figures $1 \mathrm{~b}$ and $\mathrm{S} 3$ ) and in situ XAS at the Co $\mathrm{K}$ edge reported in our previous study. ${ }^{27}$ Upon heating in the $1: 2 \mathrm{CO} / \mathrm{O}_{2}$ mixture the metallic cobalt is gradually reoxidized and $\mathrm{CO}$ conversion increases at $150-200{ }^{\circ} \mathrm{C}$. This 
is evident from operando XRD (Figure $1 \mathrm{~b}$ ) indicating metallic cobalt, $\mathrm{CoO}$ and $\mathrm{Co}_{3} \mathrm{O}_{4}$ at $200{ }^{\circ} \mathrm{C}$. At $250{ }^{\circ} \mathrm{C}$ the oxidation was still incomplete (Figure S2b). As mentioned, XRD is a bulk characterization technique, and the surface composition of the catalyst might be different, calling for surface sensitive techniques, such as X-ray photoelectron spectroscopy and infrared spectroscopy.

3.2. Operando Spectroscopy under Steady State Conditions. 3.2.1. Operando NAP-XPS. To gain spectroscopic insight into $\mathrm{CO}$ oxidation, we have utilized operando NAP-XPS, which provides surface-specific information on the cobalt oxidation state and formation of oxygen vacancies (by probing the Co $2 \mathrm{p}$ region), as well as on adsorbate species (by probing the $\mathrm{C} 1 \mathrm{~s}$ region). Within our previous study of preferential $\mathrm{CO}$ oxidation (PROX), ${ }^{27}$ CO-temperature-programmed reduction (CO-TPR) NAP-XPS indicated that $\mathrm{CO}$ reduced the top surface layers of $\mathrm{Co}_{3} \mathrm{O}_{4}$, forming $\mathrm{CoO}, \mathrm{Co}$, and oxygen vacancies, whereas elementary carbon, carbonates, and $\mathrm{CO}-\mathrm{Co}^{3+} / \mathrm{CO}-\mathrm{Co}^{2+}$ were observed in the $\mathrm{C} 1 \mathrm{~s}$ region. Similarly, herein operando NAP-XPS $(\mathrm{KE}=200 \mathrm{eV}$, probing depth $\sim 0.6 \mathrm{~nm})$ was carried out during $\mathrm{CO}$ oxidation (0.15 mbar $\mathrm{CO}$ and $0.3 \mathrm{mbar}_{2}$ ), as a function of reaction temperature (Figure 2). The assignment of Co $2 \mathrm{p}$ peaks was based on literature: ${ }^{29}$ the peak at $779.4 \mathrm{eV}$ corresponds to $\mathrm{Co}^{3+}$, the peak at $780.9 \mathrm{eV}$ to $\mathrm{Co}^{2+}$ in $\mathrm{CoO}$, and that at 782.4 $\mathrm{eV}$ to $\mathrm{Co}^{2+}$ in $\mathrm{Co}(\mathrm{OH})_{2}$.

At first, Co 2p XPS did not indicate any surface reduction of $\mathrm{Co}_{3} \mathrm{O}_{4}$ in $\mathrm{CO}+\mathrm{O}_{2}$, neither at $\mathrm{RT}$ nor at higher temperature (i.e., there were no shakeup satellites) ${ }^{29,30}$ (Figure 2a). To better reveal changes, all spectra were normalized, plotted together (Figure S4a) and a difference spectrum of spectra at $200{ }^{\circ} \mathrm{C}$ and RT was calculated (Figure S4b), which point to minor surface reduction at the detection level at $200{ }^{\circ} \mathrm{C}$. Note that (pure) $\mathrm{CO}$ induced surface reduction and formation of oxygen vacancies particularly above $100{ }^{\circ} \mathrm{C} .{ }^{27}$ Thus, during $\mathrm{CO}$ oxidation (i.e., in the presence of an excess of $\mathrm{O}_{2}$ ) only minute surface reduction occurred. This indicates a rapid dynamic reduction/reoxidation of the cobalt oxide surface in the $\mathrm{CO}+\mathrm{O}_{2}$ mixture under steady state. Catalytic data recorded in parallel to NAP-XPS (Figure 2b) agreed with those from the fixed-bed flow reactor.

The $\mathrm{C} 1 \mathrm{~s}$ region revealed three peaks during $\mathrm{CO}$ oxidation (Figure 2c), characterizing carbonates $(288.2 \mathrm{eV}))^{31-33}$ elementary carbon $(284.7 \mathrm{eV}){ }^{34}$ and $\mathrm{CO}$ adsorbed to cobalt (i.e., $\left.\mathrm{CO}-\mathrm{Co}^{3+} / \mathrm{CO}-\mathrm{Co}^{2+}\right)(286.1 \mathrm{eV}) .^{35}$ The peak positions and fwhm are listed in Table S1. The absolute amount of elementary carbon, carbonates, and weakly adsorbed $\mathrm{CO}$ increased from RT to $100{ }^{\circ} \mathrm{C}$, but decreased upon further heating (Figure $2 \mathrm{~d}$ ). The relative amount of $\mathrm{C}$ was $32 \%$ at $\mathrm{RT}$ and $44-47 \%$ at $100-200{ }^{\circ} \mathrm{C}$ (Figure 2e), assuming identical sensitivity for all species.

In contrast, during CO-TPR $\left(\mathrm{O}_{2}\right.$ absent) the intensity of carbon species increased with temperature. ${ }^{27}$ The ratio of elementary carbon to carbonates and adsorbed $\mathrm{CO}$ was larger: the fraction of $\mathrm{C}$ was $52 \%$ at $\mathrm{RT}$ and $78 \%$ at $200{ }^{\circ} \mathrm{C} .{ }^{27}$ Also, increasing temperature in $\mathrm{CO}$ led to $\mathrm{Co}_{3} \mathrm{O}_{4}$ reduction to $\mathrm{CoO}_{x}$ and formation of oxygen vacancies. Since the $\mathrm{C}$ concentration was much higher in pure $\mathrm{CO}$, the oxygen vacancies are likely the reaction sites of $\mathrm{CO}$ dissociation (cooperating with neighboring Co cations). In the presence of oxygen, vacancies are refilled and less carbon is produced. Thus, $\mathrm{O}_{2}$ of the reaction mixture may hinder the growth of $\mathrm{C}$ by keeping the surface oxidized and thus preventing $\mathrm{CO}$ dissociation, or $\mathrm{O}_{2}$ just reoxidizes $\mathrm{C}$ deposited by $\mathrm{CO}$ dissociation.

3.2.2. Operando FTIR Spectroscopy. Operando FTIR spectroscopy enables studying adsorbed species, thus contributing in identifying reaction pathways. A number of IR studies have reported carbonates, ${ }^{4,13,14,32}$ but their exact role, whether being reaction intermediates, spectators, or poisons remained unclear. Carbonates have also frequently been observed for CO-containing reactions on oxide supported metals. $^{36,37}$ Systematic operando FTIR studies were performed to unravel their role, applying three feed compositions (Figure 3): $\mathrm{CO} / \mathrm{O}_{2}=1: 2 ; 1: 1 ; 2: 1$.

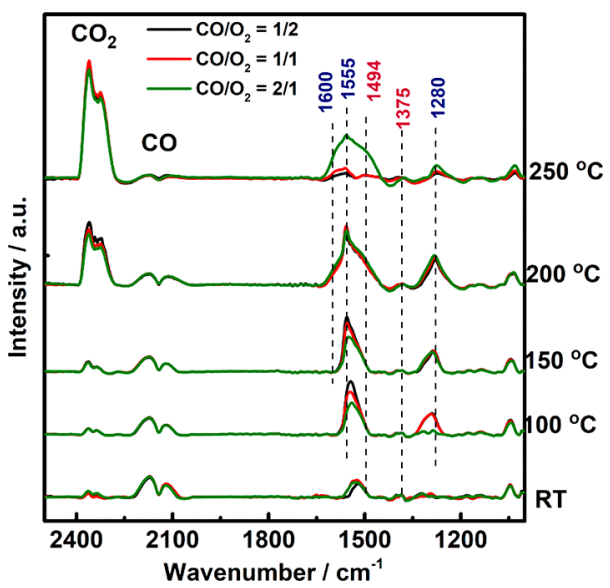

Figure 3. Operando FTIR spectra recorded during $\mathrm{CO}$ oxidation on $\mathrm{Co}_{3} \mathrm{O}_{4}$ in flow mode $\left(25 \mathrm{~mL} \mathrm{~min}{ }^{-1}\right)$ from $\mathrm{RT}$ to $250{ }^{\circ} \mathrm{C}$ in different gas mixtures: 50 mbar $\mathrm{CO}, 100$ mbar $\mathrm{O}_{2}$ (black); 50 mbar $\mathrm{CO}, 50$ mbar $\mathrm{O}_{2}$ (red); and 50 mbar CO, 25 mbar $\mathrm{O}_{2}$ (green).

All operando FTIR spectra exhibited the characteristic gasphase bands of CO $\left(2110\right.$ and $\left.2170 \mathrm{~cm}^{-1}\right)$ as well as bands in the $1000-1650 \mathrm{~cm}^{-1}$ region, attributed to various carbonate vibrations. In contrast to NAP-XPS, operando FTIR did not show any bands of (linearly adsorbed) $\mathrm{CO}$ on $\mathrm{Co}^{2+}$ or $\mathrm{Co}^{3+}$. The CO stretching frequencies of cobalt carbonyls were reported at $2023-2025 \mathrm{~cm}^{-1}$ for metallic cobalt, 2070-2110 $\mathrm{cm}^{-1}$ for $\mathrm{Co}^{+}, 2120-2170 \mathrm{~cm}^{-1}$ for $\mathrm{Co}^{2+}$, and $2178-2180$ $\mathrm{cm}^{-1}$ for $\mathrm{Co}^{3+} .{ }^{14}$ Thus, the $2178-2180 \mathrm{~cm}^{-1}$ on $\mathrm{Co}^{3+}$ band could be masked by gas-phase CO.

In the FTIR cell, carbonate formation started at RT whereas $\mathrm{CO}_{2}$ production began around $150{ }^{\circ} \mathrm{C}$, increasing with temperature. The assignment of surface carbonates is based on literature ${ }^{38,39}$ and IR stretching vibrations are presented in Table S3. The carbonates at RT were mainly monodentates (1494, 1375, $\left.1320 \mathrm{~cm}^{-1}\right)$. Upon temperature increase, bidentates evolved (additional bands at 1620, 1555, and $\left.1280 \mathrm{~cm}^{-1}\right)$. It is important to note that all FTIR spectra were recorded on the same pellet of $\mathrm{Co}_{3} \mathrm{O}_{4}$, allowing to quantitatively compare intensities and the amount of adsorbed species.

FTIR spectra of the three gas mixtures mainly differed in the stability of the carbonates. Under $\mathrm{O}_{2}$-rich conditions $\left(\mathrm{CO} / \mathrm{O}_{2}\right.$ $=1$ to 2 ) the signal intensity increased from $\mathrm{RT}$ to $170{ }^{\circ} \mathrm{C}$, between $170{ }^{\circ} \mathrm{C}$ and $200{ }^{\circ} \mathrm{C}$ additional bidentate carbonates were formed, but at $220{ }^{\circ} \mathrm{C}$ carbonates started to disappear and no carbonates were present above $220{ }^{\circ} \mathrm{C}$ (Figure 3). The appearance of bidentate carbonates was accompanied by an increase in $\mathrm{CO}$ conversion $\left(\mathrm{CO}_{2}\right.$ gas-phase peak; Figure 3). 

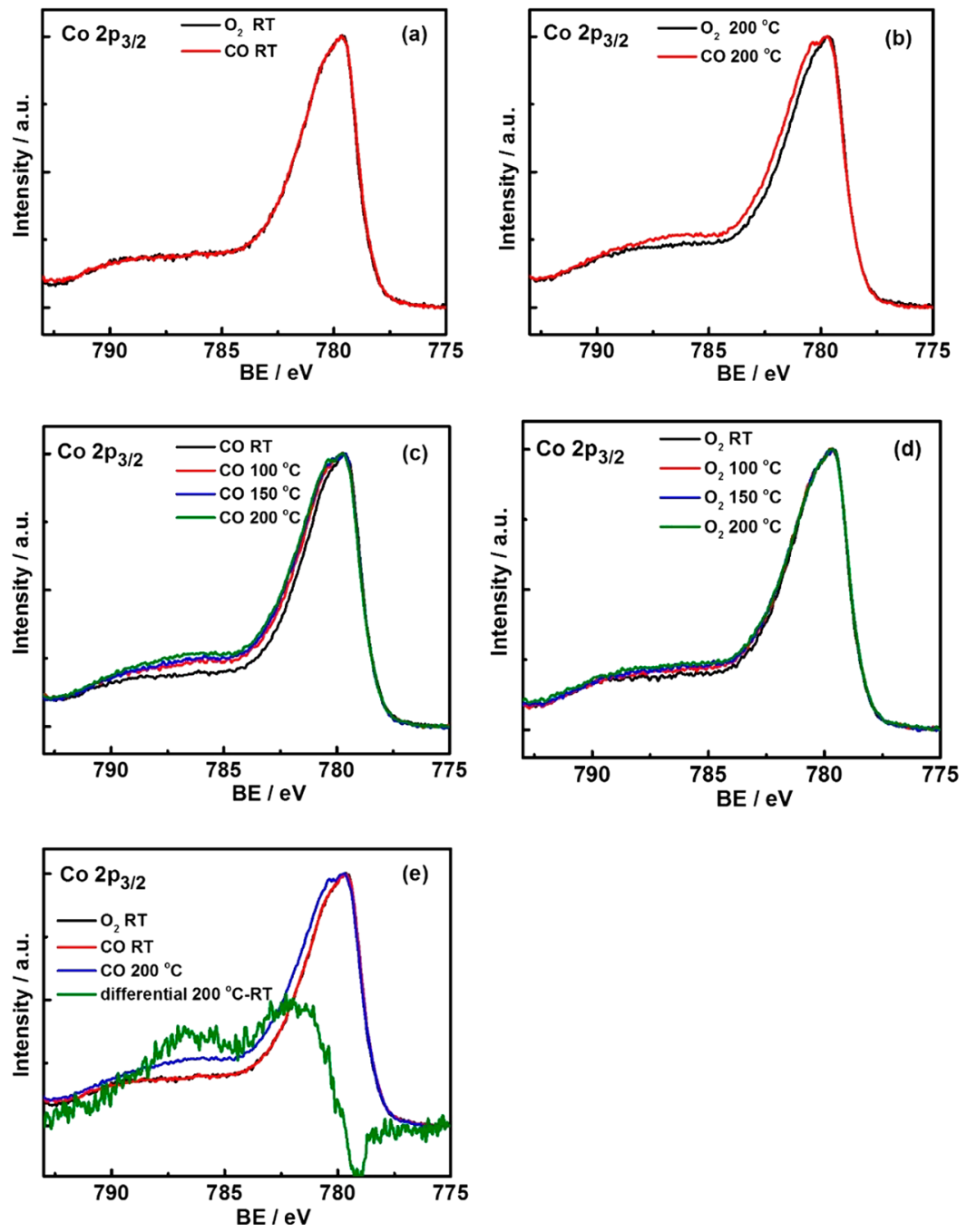

Figure 4. Operando NAP-XPS on $\mathrm{Co}_{3} \mathrm{O}_{4}$ during $\mathrm{CO} / \mathrm{O}_{2}$ switching $\left(0.15 \mathrm{mbar} \mathrm{CO}\right.$ vs 0.15 mbar $\left.\mathrm{O}_{2}\right), \mathrm{Co}_{2} \mathrm{p}_{3 / 2}$ region $(h \nu=1015 \mathrm{eV}$; $\mathrm{KE}=200$ $\mathrm{eV}$ ): comparison in $\mathrm{CO}$ and $\mathrm{O}_{2}$ at (a) RT and (b) $200{ }^{\circ} \mathrm{C}$; the Co $2 \mathrm{p}_{3 / 2}$ region at various temperatures in (c) $\mathrm{CO}$ and $(\mathrm{d}) \mathrm{O}_{2}$; (e) difference spectrum ( Co $2 \mathrm{p}_{3 / 2} 200{ }^{\circ} \mathrm{C}$ in CO-Co $2 \mathrm{p}_{3 / 2} \mathrm{RT}$ in $\mathrm{O}_{2}$ ).
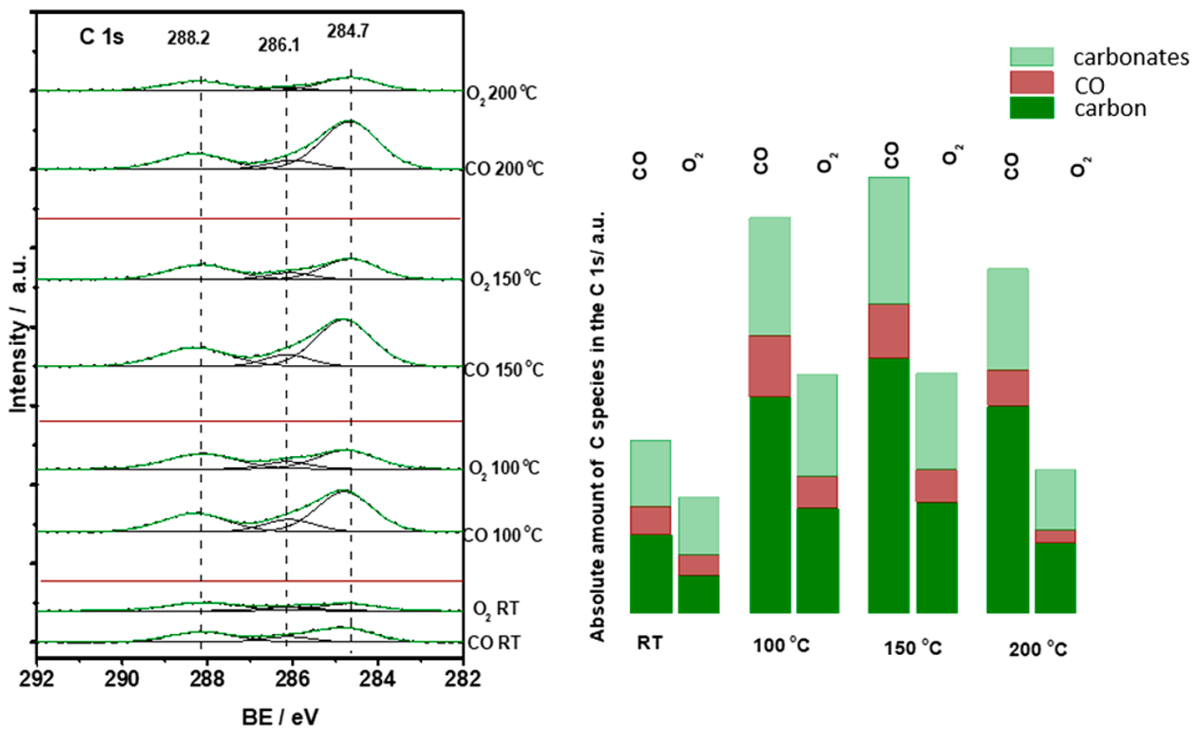

Figure 5. Operando NAP-XPS C 1 s region $(h \nu=465 \mathrm{eV} ; \mathrm{KE}=200 \mathrm{eV})$ on $\mathrm{Co}_{3} \mathrm{O}_{4}$ during $\mathrm{CO} / \mathrm{O}_{2}$ switching $\left(0.15 \mathrm{mbar} \mathrm{CO}\right.$ vs $\left.0.15 \mathrm{mbar} \mathrm{O}_{2}\right)$. The absolute amount of carbon species was calculated from a linear peak fit. 
The disappearance of carbonate peaks was accompanied by a further increase of the $\mathrm{CO}_{2}$ gas-phase peak and an overall increase of $\mathrm{CO}$ conversion. The decreasing carbonate intensity above $220{ }^{\circ} \mathrm{C}$ is likely due to lower stability of carbonates in $\mathrm{O}_{2}$ excess.

In the reaction mixture with an initial $\mathrm{CO} / \mathrm{O}_{2}$ ratio of $1: 1$, a relatively high amount of carbonates was still present at $220^{\circ} \mathrm{C}$ and higher temperatures were required to make them disappear. When the $\mathrm{CO}$ to $\mathrm{O}_{2}$ ratio was stoichiometric $\left(\mathrm{CO} / \mathrm{O}_{2}=2: 1\right)$, the amount of carbonates was even higher and the concentration of carbonates increased continuously up to $250{ }^{\circ} \mathrm{C}$.

In summary, the more reducing ( $\mathrm{CO}$ rich) the reaction atmosphere was, the higher the amount and stability of surface carbonates became. This suggests that upon temperature increase more sites were formed (likely by reduction of the $\mathrm{Co}_{3} \mathrm{O}_{4}$ surface), that were active for $\mathrm{CO}$ adsorption and carbonate formation. Whether excess $\mathrm{O}_{2}$ reduces the amount of carbonates formed or just facilitates carbonate decomposition/desorption to $\mathrm{CO}_{2}$ cannot be answered at this point. On the basis of static IR experiments, the potential contribution of carbonates to the overall activity cannot be assessed. Thus, gas switching experiments were performed both for NAP-XPS and FTIR.

3.3. Operando Spectroscopy upon Switching between $\mathrm{CO}$ and $\mathrm{O}_{2}$. 3.3.1. NAP-XPS. To lift the limitations of steady state spectroscopy, switching experiments were monitored by NAP-XPS (Figures 4, 5, S6, S7, and S8). CO/ $\mathrm{O}_{2}$ switching (each $0.15 \mathrm{mbar}$ for $\sim 50 \mathrm{~min}$ ) was carried out at $\mathrm{RT}, 100{ }^{\circ} \mathrm{C}, 150^{\circ} \mathrm{C}$, and $200{ }^{\circ} \mathrm{C}$, simultaneously recording Co $2 \mathrm{p}$ and $\mathrm{C} 1 \mathrm{~s}$ spectra $(\mathrm{KE}=200 \mathrm{eV}$; Figures 4, 5, and S7) and MS of reactants and $\mathrm{CO}_{2}$ (Figure S6). Taking into account the attenuation of photoelectrons in the gas phase, a $\mathrm{CO} / \mathrm{O}_{2}$ ratio of 1 was used $\left(0.15\right.$ mbar $\mathrm{CO}$ vs $0.15 \mathrm{mbar}_{2}$; similar scattering was confirmed by comparing Co $2 \mathrm{p}$ peak intensities).

Figure $\mathrm{S} 6 \mathrm{~b}$ demonstrates that changing the atmosphere from $\mathrm{O}_{2}$ to $\mathrm{CO}$ produced $\mathrm{CO}_{2}$ already at RT, but increased with temperature. Note that before introducing the reacting gas (e.g., CO) into the NAP-XPS chamber, the other reacting gas (e.g., $\mathrm{O}_{2}$ ) was evacuated from the chamber, in order to keep the $\mathrm{Co}_{3} \mathrm{O}_{4}$ catalyst free from physisorbed molecules.

A significant increase in $\mathrm{CO}_{2}$ evolution at $200{ }^{\circ} \mathrm{C}$ and continuous $\mathrm{CO}_{2}$ production for $\sim 30$ min upon switching to $\mathrm{CO}$ indicates that not only surface lattice oxygen may take part in $\mathrm{CO}_{2}$ production, but also oxygen from the bulk. The shape of the MS curve, a sharp peak followed by a slow decrease, points to fast reaction with surface oxygen (decaying fast upon consumption) and a slower reaction with bulk oxygen, which needs to diffuse to the surface. If only surface oxygen would react, then $\mathrm{CO}_{2}$ production should have dropped quickly. A gradual (slow) decrease in $\mathrm{CO}_{2}$ evolution is observed at 200 ${ }^{\circ} \mathrm{C}$, which may be caused by catalyst deactivation by carbon ( $\mathrm{C}$ 1 s region, Figure 5) or by slow diffusion of oxygen from deeper (bulk) layers.

$\mathrm{CO}$ disproportionation to $\mathrm{C}$ and $\mathrm{CO}_{2}$ may also contribute to the slower pathway. The amount of $\mathrm{CO}_{2}$ produced at $200{ }^{\circ} \mathrm{C}$ during steady state $\mathrm{CO}$ oxidation $(0.15 \mathrm{mbar} \mathrm{CO}$ and $0.3 \mathrm{mbar}$ $\mathrm{O}_{2}$; Figure $2 \mathrm{~b}$ ) was $1.34 \times 10^{-10}$ a.u. The amount of $\mathrm{CO}_{2}$ produced at $200{ }^{\circ} \mathrm{C}$ in the presence of pure $\mathrm{CO}(0.15 \mathrm{mbar}$ $\mathrm{CO}$; Figure S6b) was $6.10 \times 10^{-12}$ a.u. (after $\sim 5 \mathrm{~min}$ ) and 3.61 $\times 10^{-12}$ a.u. (after $\sim 30 \mathrm{~min}$ ) that is $22-37$ times lower than the catalytic activity in $\mathrm{CO}+\mathrm{O}_{2}$.
In the opposite case, when $\mathrm{O}_{2}$ was introduced after $\mathrm{CO}$, there was only minor $\mathrm{CO}_{2}$ production, likely due to surface carbonate decomposition (and then $\mathrm{O}_{2}$ reoxidized the surface). The MS data were confirmed by analogous experiments in the catalytic flow reactor.

Figures 4 and 5 display the corresponding Co $2 \mathrm{p}_{3 / 2}$ and $\mathrm{C} 1 \mathrm{~s}$ spectra. Upon switching to $\mathrm{CO}$, the $\mathrm{Co}_{3} \mathrm{O}_{4}$ surface oxidation state did not change at RT (no satellites appeared in Co $2 \mathrm{p}$ ), whereas more pronounced changes of $\mathrm{Co}^{3+} / \mathrm{Co}^{2}$ were observed at higher temperature, especially at $200{ }^{\circ} \mathrm{C}$ (Figures $4 \mathrm{a}, \mathrm{b}$, and S7). In $\mathrm{CO}$ at $200{ }^{\circ} \mathrm{C}$, the $\mathrm{Co}^{3+}$ concentration decreased by $15 \%$, as compared to $\mathrm{O}_{2}$. The amount of reduced sites upon switching was quantified via the spectral intensities (i.e., the ratio between $\mathrm{Co}_{3} \mathrm{O}_{4}$ and $\mathrm{CoO}$ ). This indicates that $\mathrm{CO}$ reduces part of the surface, while $\mathrm{O}_{2}$ reoxidizes it, as expected for the Mars-van-Krevelen mechanism (which has been proven by numerous experimental and theoretical studies. $5,12,13,18-21)$ Figure $4 \mathrm{~d}$ suggests that reoxidation $(0.15$ mbar $\mathrm{O}_{2}$ ) was not complete though, but a tiny amount of reduced $\mathrm{Co}^{2+}$ species persisted.

With respect to the $\mathrm{C} 1 \mathrm{~s}$ region, elementary carbon increased with temperature in $\mathrm{CO}$, whereas switching to $\mathrm{O}_{2}$ strongly decreased the (amorphous) carbon (interestingly, $\mathrm{O}_{2}$ partially oxidizes carbon even at RT) (Figures 5 and S8). Thus, it is possible that a (minor) reaction pathway toward $\mathrm{CO}_{2}$ proceeds via $\mathrm{CO}$ dissociation followed by carbon oxidation to $\mathrm{CO} / \mathrm{CO}_{2}$. In contrast, the carbonates decreased to a considerably lower extent at higher temperature, indicating that carbonate decomposition was more difficult than the reoxidation of carbon.

Carbonate formation has been previously reported for $\mathrm{Co}_{3} \mathrm{O}_{4}$, ${ }^{4,13,14}$ but the observed carbon deposition has been scarcely discussed in literature (indirect investigations by Jansson ${ }^{12,13}$ in the course of isotope studies). The current $\mathrm{C} 1 \mathrm{~s}$ NAP-XPS data directly indicate carbon formation on $\mathrm{Co}_{3} \mathrm{O}_{4}$ during $\mathrm{CO}$ exposure and $\mathrm{CO}$ oxidation.

The simultaneous NAP-XPS/MS observations are in line with the redox Mars-van-Krevelen mechanism, but also point to a possible contribution of $\mathrm{CO}$ dissociation, elementary carbon deposition, and carbon reoxidation the extent of which is however unknown. The role of the various carbonates remains ambiguous, why "switching" operando FTIR spectroscopy was employed.

3.3.2. FTIR Spectroscopy. Figure 6 shows operando FTIR spectra upon $\mathrm{CO} / \mathrm{O}_{2}$ switching ( $50 \mathrm{mbar} \mathrm{CO}$ vs 50 mbar $\mathrm{O}_{2}$ ) on $\mathrm{Co}_{3} \mathrm{O}_{4}$. CO was introduced first and consecutive IR spectra were acquired for $10 \mathrm{~min}$ (each spectrum taking about $2 \mathrm{~min}$ ), then the atmosphere was changed to $\mathrm{O}_{2}$ and IR spectra were acquired after 2 and $10 \mathrm{~min}$. Then, $\mathrm{Co}_{3} \mathrm{O}_{4}$ was heated in $\mathrm{O}_{2}$ to the next temperature before introducing $\mathrm{CO}$ again (performed at RT, $100{ }^{\circ} \mathrm{C}, 150{ }^{\circ} \mathrm{C}, 200{ }^{\circ} \mathrm{C}$, and $250^{\circ} \mathrm{C}$ ). FTIR shows that neither at RT nor at $100{ }^{\circ} \mathrm{C}$ carbonate decomposition by $\mathrm{O}_{2}$ took place, not even during $10 \mathrm{~min} \mathrm{O}_{2}$ exposure. Mainly monodentate carbonates, apparently being quite stable, were present. At $150{ }^{\circ} \mathrm{C}$, the carbonate peak area decreased during the first $2 \mathrm{~min}$, and higher temperature decreased both monoand bidentate carbonates. At $200{ }^{\circ} \mathrm{C}$ and $250{ }^{\circ} \mathrm{C}$, the carbonates strongly decreased after $2 \mathrm{~min}$ and after $10 \mathrm{~min}$ no carbonates were present anymore (Figure 6). Overall, the surface carbonates seemed rather stable spectators, with their intensity decreasing rather slowly and mostly at high temperature, which rather excludes carbonates as reaction intermediates of fast $\mathrm{CO}$ oxidation. Thus, carbonate 


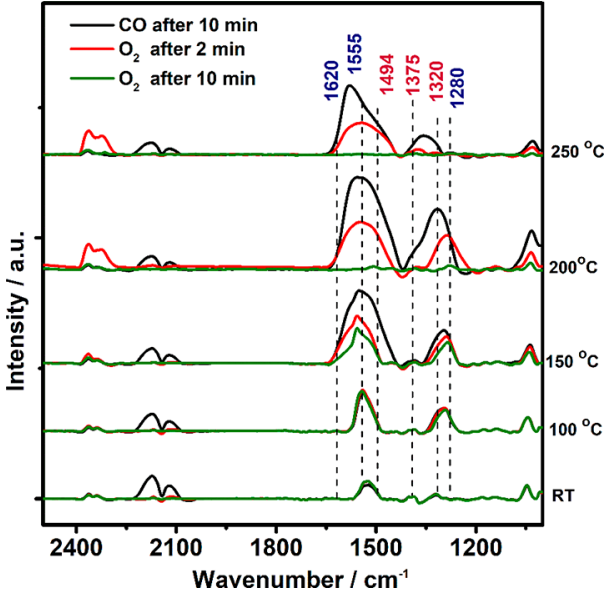

Figure 6. Operando FTIR on $\mathrm{Co}_{3} \mathrm{O}_{4}$ upon $\mathrm{CO} / \mathrm{O}_{2}$ switching experiments ( $50 \mathrm{mbar} \mathrm{CO}$ vs $50 \mathrm{mbar} \mathrm{O}_{2}$ ): spectra recorded during the $10^{\text {th }}$ minute of $\mathrm{CO}$ exposure (black), during the $2^{\text {nd }}$ minute of $\mathrm{O}_{2}$ exposure (red) and during the $10^{\text {th }}$ minute of $\mathrm{O}_{2}$ exposure (green).

formation/decomposition plays rather a minor role beside fast $\mathrm{CO}$ oxidation (MvK). Deactivation/site blocking by carbonates can also rather be excluded.

3.4. Carbonate Formation and Stability: FTIR Spectroscopy. 3.4.1. Interaction of $\mathrm{CO}_{3} \mathrm{O}_{4}$ with Carbon Monoxide. To further examine carbonate formation, reactivity and stability, the interaction of $\mathrm{CO}$ with $\mathrm{Co}_{3} \mathrm{O}_{4}$ was studied by FTIR from RT to $350{ }^{\circ} \mathrm{C}$ (Figure $7 \mathrm{a}$ ). Similar to $\mathrm{CO}+\mathrm{O}_{2}$, no adsorbed $\mathrm{CO}$ but only carbonates were observed. Mainly monodentate carbonates were formed at RT, bidentate carbonates emerged at $100{ }^{\circ} \mathrm{C}$, and the overall carbonate intensity increased with temperature. This suggests that at higher temperature more reactive sites are formed that enable $\mathrm{CO}$ adsorption as a carbonate. Recall that NAP-XPS revealed partial reduction of the $\mathrm{Co}_{3} \mathrm{O}_{4}$ surface and surface oxygen vacancy formation in $\mathrm{CO}$, especially from $100{ }^{\circ} \mathrm{C}$ to $200{ }^{\circ} \mathrm{C} .{ }^{27}$ When more vacancies were created, $\mathrm{CO}$ could adsorb as carbonate. Accordingly, heating in $\mathrm{CO}$ favors lattice oxygen extraction, increasing the concentration of carbonates. Note that in $\mathrm{CO}$ the amount of carbonates was significantly higher than that during $\mathrm{CO}$ oxidation (even in a stoichiometric mixture at low temperature) (Figure S9). The higher concentration of carbonates in $\mathrm{CO}$ as compared to $\mathrm{O}_{2}$ containing feed suggests that partial $\mathrm{Co}_{3} \mathrm{O}_{4}$ surface reduction is beneficial for carbonate formation. This will be discussed in the following.

3.4.2. Investigation of Carbonate Stability in $\mathrm{O}_{2}$ and $\mathrm{He}$ Atmosphere. The thermal stability of carbonates was examined in $\mathrm{O}_{2}$ and $\mathrm{He}$ atmospheres. FTIR spectra were recorded after exposing $\mathrm{Co}_{3} \mathrm{O}_{4}$ to $\mathrm{CO}$ at $200{ }^{\circ} \mathrm{C}$ and cooling in $\mathrm{CO}$ to RT (i.e., initial spectrum) and during heating in 50 mbar $\mathrm{O}_{2}$ in $\mathrm{He}$ or in pure $\mathrm{He}$. As evident from Figure $7 \mathrm{~b}$, introducing $\mathrm{O}_{2}$ at $\mathrm{RT}$ already changed the carbonates, forming

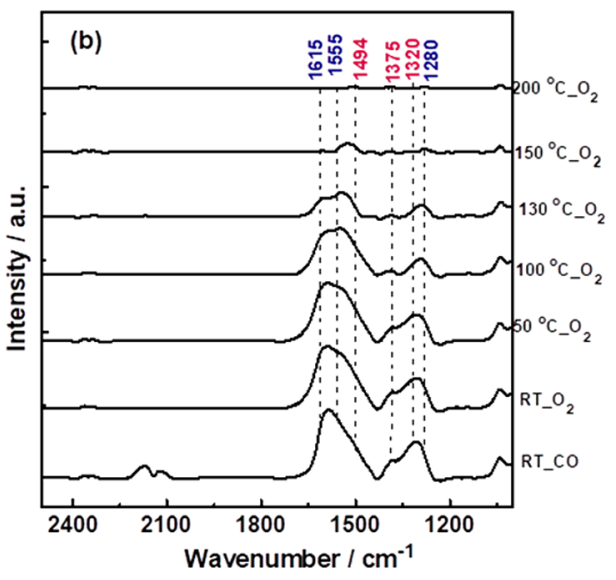

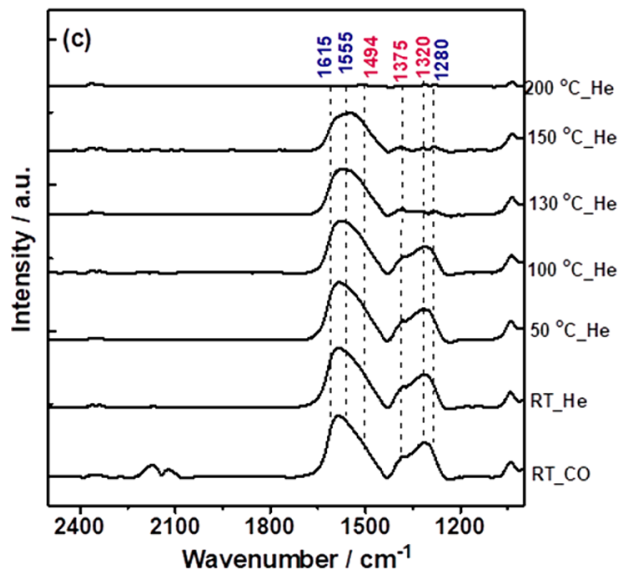

Figure 7. FTIR spectra on $\mathrm{Co}_{3} \mathrm{O}_{4}$ recorded during: (a) adsorption of $\mathrm{CO}\left(50 \mathrm{mbar}\right.$ ) in flow mode (total flow $25 \mathrm{~mL} \mathrm{~min}^{-1}$ ) from RT to $350{ }^{\circ} \mathrm{C}$; (b) pretreatment with $\mathrm{CO}$ at $200{ }^{\circ} \mathrm{C}$, cooling in $\mathrm{CO}$ to $\mathrm{RT}$ and heating in $\mathrm{O}_{2}\left(100 \mathrm{mbar}_{2}\right.$ bar in $\mathrm{He}$, total flow $25 \mathrm{~mL}$ min $\left.{ }^{-1}\right)$; and (c) pretreatment with $\mathrm{CO}$ at $200{ }^{\circ} \mathrm{C}$, cooling in $\mathrm{CO}$ to $\mathrm{RT}$ and heating in He (total flow $25 \mathrm{~mL} \mathrm{~min}{ }^{-1}$ ). 


\section{(1) Interaction of $\mathrm{CO}$ with $\mathrm{Co}_{3} \mathrm{O}_{4}$, formation of oxygen vacancies}

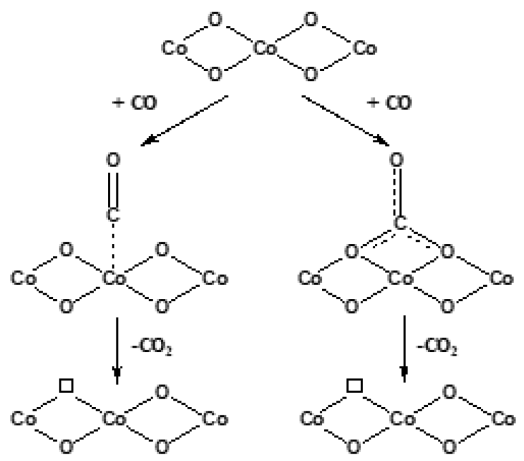

(2) Interaction of oxygen vacancies with $\mathrm{O}_{3}$, CO dissociation

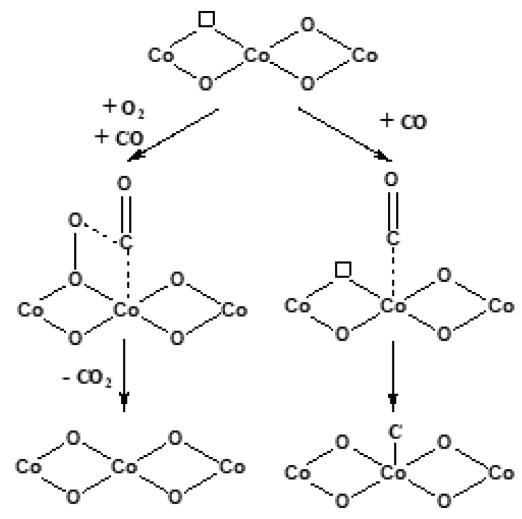

(3) Carbon oxidation

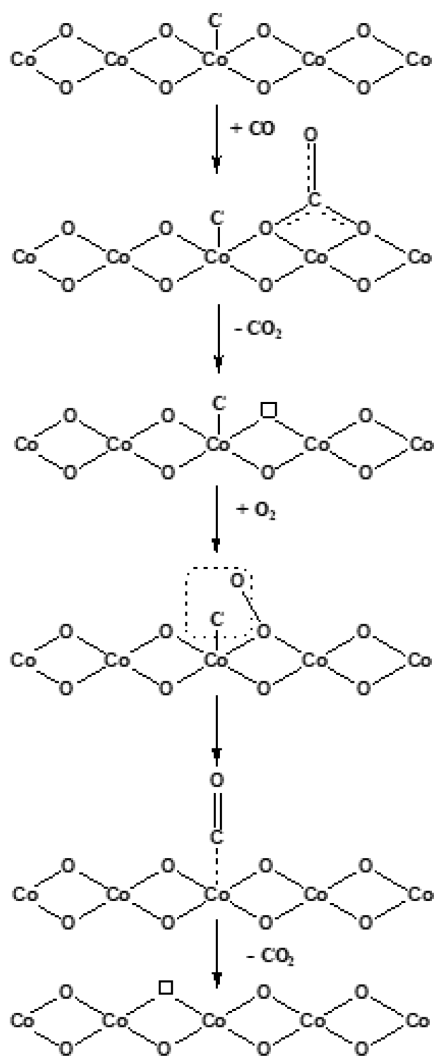

Figure 8. Schematic representation of $\mathrm{CO}$ oxidation on $\mathrm{Co}_{3} \mathrm{O}_{4}$.

additional monodentate carbonates appearing as a shoulder at $\sim 1530-1470 \mathrm{~cm}^{-1}$. Heating in $\mathrm{O}_{2}$ to $100{ }^{\circ} \mathrm{C}$ decomposed both mono- and bidentate carbonates. At $130{ }^{\circ} \mathrm{C}$, the intensity of carbonate bands decreased to $1 / 3$ of its initial value. At 150 ${ }^{\circ} \mathrm{C}$, only a small amounts of monodentate carbonates were left on the cobalt oxide surface, while at $200{ }^{\circ} \mathrm{C}$ it was free of carbonates.

The thermal stability of carbonates was also studied in $\mathrm{He}$ (Figure 7c). Again, FTIR spectra were recorded after exposing $\mathrm{Co}_{3} \mathrm{O}_{4}$ to $\mathrm{CO}$ at $200{ }^{\circ} \mathrm{C}$, cooling down in $\mathrm{CO}$ to $\mathrm{RT}$ and heating in $\mathrm{He}$. Up to $100{ }^{\circ} \mathrm{C}$, no significant carbonate decomposition was observed. At $130{ }^{\circ} \mathrm{C}$, carbonates started to decompose. However, the decrease was faster for the 1380$1280 \mathrm{~cm}^{-1}$ peaks than for the $1600-1430 \mathrm{~cm}^{-1}$ peaks, indicating different thermal stability and reactivity of surface carbonates. Importantly, at $150{ }^{\circ} \mathrm{C}$ carbonates were still detected in $\mathrm{He}$, whereas in $\mathrm{O}_{2}$ only a small amount was present. The observation of carbonate peaks disappearing at about $200{ }^{\circ} \mathrm{C}$ is in agreement with CO-TPD reported in our previous study ( $\mathrm{CO}$ exposure at RT for $30 \mathrm{~min}$ followed by heating in $\mathrm{He}$ to $700{ }^{\circ} \mathrm{C}$ ). ${ }^{27}$ Only $\mathrm{CO}_{2}$ evolved (and no $\mathrm{CO}$ ) suggesting lattice oxygen extraction from cobalt oxide.

3.4.3. Interaction of $\mathrm{CO}_{3} \mathrm{O}_{4}$ with Carbon Dioxide. The results presented so far $\left(\mathrm{CO}\right.$ vs $\left.\mathrm{CO} / \mathrm{O}_{2}\right)$ suggest that carbonate formation requires, or is at least facilitated, by partial surface reduction by CO. However, it is still unclear whether carbonates may also form by readsorption of the reaction product $\mathrm{CO}_{2}$. Thus, preoxidized $\mathrm{Co}_{3} \mathrm{O}_{4}$ was exposed to $\mathrm{CO}_{2}$ at $\mathrm{RT}$ and heated to $200{ }^{\circ} \mathrm{C}$ (Figure S10a).
Interestingly, neither at $\mathrm{RT}$ nor during heating any $\mathrm{CO}_{2}$ adsorption/carbonate was observed; $\mathrm{CO}_{2}$ remained in the gas phase $\left(2336\right.$ and $2360 \mathrm{~cm}^{-1}$ ). This is in contrast to $\mathrm{CO}_{2}$ adsorption on many other oxides such as $\mathrm{ZrO}_{2}{ }^{38,40}$ or $\mathrm{Al}_{2} \mathrm{O}_{3}{ }^{41}$ when $\mathrm{CO}_{2}$ easily forms carbonates. The different affinity to $\mathrm{CO}_{2}$ may be due to specific active sites or functional groups (i.e., $\mathrm{OH}$, basic surface oxygen) that are missing on $\mathrm{Co}_{3} \mathrm{O}_{4}$.

In another series of experiments, the interaction of $\mathrm{CO}_{2}$ with $\mathrm{Co}_{3} \mathrm{O}_{4}$ prereduced by $\mathrm{CO}$ or $\mathrm{H}_{2}$ (intended to create oxygen vacancies that seem required for $\mathrm{CO}_{2}$ adsorption) was examined. (Figures S10b, S11, and S12). However, there was no $\mathrm{CO}_{2}$ adsorption or carbonate formation under all conditions. Thus, it can be ruled out that the observed carbonates originate from $\mathrm{CO}_{2}$ readsorption. Rather, they are only formed by direct interaction of $\mathrm{Co}_{3} \mathrm{O}_{4}$ with $\mathrm{CO}$ that partly reduces the $\mathrm{Co}_{3} \mathrm{O}_{4}$ surface. The higher concentration of surface carbonates in $\mathrm{CO}$ as compared to $\mathrm{O}_{2}$-containing feed also suggests this picture.

\subsection{DISCUSSION}

Using operando NAP-XPS, FTIR, and XRD we have examined the (surface) oxidation state of $\mathrm{Co}_{3} \mathrm{O}_{4}$ and adsorbates present during $\mathrm{CO}$ oxidation, and compared them with those in pure $\mathrm{CO}$ and upon switching between $\mathrm{CO}$ and $\mathrm{O}_{2}$. In particular, the comparison of static (steady-state) and switching experiments provided valuable information.

Combining information from NAP-XPS/FTIR and activity tests revealed a complex network of different reaction pathways contributing to $\mathrm{CO}$ oxidation on $\mathrm{Co}_{3} \mathrm{O}_{4}$. In the following $\mathrm{O}_{\text {surf }}$ 
$\mathrm{O}_{\#}$, and $\mathrm{O}_{\text {ads }}$ refer to surface (lattice) oxygen, oxygen (surface) vacancies, and adsorbed atomic oxygen. Some pathways are reversible, others have been shown to be irreversible.

(1) Direct MvK pathway:

$$
\begin{aligned}
& \mathrm{CO}_{\text {gas }} \Leftrightarrow \mathrm{CO}_{\mathrm{ads}} \\
& \mathrm{CO}_{\mathrm{ads}}+\mathrm{O}_{\text {surf }} \rightarrow \mathrm{CO}_{2 \mathrm{ads}}+\mathrm{O}_{\#} \\
& \mathrm{CO}_{2 \mathrm{ads}} \rightarrow \mathrm{CO}_{2 \text { gas }} \\
& \mathrm{O}_{\#}+\mathrm{O}_{2 \text { gas }} \rightarrow \mathrm{O}_{\text {surf }}+\mathrm{O}_{\mathrm{ads}}
\end{aligned}
$$

(2) via $\mathrm{CO}$ dissociation and carbon oxidation:

$$
\begin{aligned}
& \mathrm{CO}_{\mathrm{gas}} \Leftrightarrow \mathrm{CO}_{\mathrm{ads}} \\
& \mathrm{CO}_{\mathrm{ads}}+\mathrm{O}_{\#} \Leftrightarrow \mathrm{C}_{\mathrm{ads}}+\mathrm{O}_{\text {surf }} \\
& \mathrm{C}_{\mathrm{ads}}+\mathrm{O}_{\#}+\mathrm{O}_{2 \mathrm{gas}} \Leftrightarrow \mathrm{CO}_{\mathrm{ads}}+\mathrm{O}_{\text {surf }} \rightarrow \mathrm{CO}_{2 \mathrm{ads}} \\
& \mathrm{CO}_{2 \mathrm{ads}} \rightarrow \mathrm{CO}_{2 \mathrm{gas}}
\end{aligned}
$$

(3) via carbonates as intermediates:

$$
\begin{aligned}
& \mathrm{CO}_{\text {ads }}+2 \mathrm{O}_{\text {surf }} \rightarrow \mathrm{OCOO}_{\text {carbonate }} \rightarrow \mathrm{CO}_{2 \mathrm{ads}}+\mathrm{O}_{\#} \\
& \mathrm{CO}_{2 \mathrm{ads}} \rightarrow \mathrm{CO}_{2 \text { gas }} \\
& \mathrm{O}_{\#}+\mathrm{O}_{2 \text { gas }} \rightarrow \mathrm{O}_{\text {surf }}+\mathrm{O}_{\text {ads }}
\end{aligned}
$$

Operando NAP-XPS and FTIR spectroscopy-in particular based on switching experiments-were in accordance with a fast $\mathrm{CO}$ oxidation route via a Mars-van-Krevelen mechanism (1), i.e., alternating reduction-oxidation of the $\mathrm{Co}_{3} \mathrm{O}_{4}$ surface by $\mathrm{CO}$ and $\mathrm{O}_{2}$. Carbon monoxide adsorbed to cobalt cations reacts with lattice surface oxygen, and the created oxygen vacancies $\left(\mathrm{O}_{\#}\right)$ are replenished by $\mathrm{O}_{2}$ from the gas phase, further creating active $\mathrm{O}_{\text {ads }}$ species.

In addition, adsorbed $\mathrm{CO}$ (likely near $\mathrm{O}_{\#}$ ) may undergo dissociation, filling an oxygen vacancy and depositing elementary carbon on the surface, which can be reoxidized by $\mathrm{O}_{2}$ (once more near $\mathrm{O}_{\#}$ ) (2). CO dissociation likely occurs at/near oxygen vacancies, as indicated by the larger amount of carbon present under more reducing conditions when more oxygen vacancies are formed. The carbon is quite reactive and is oxidized even at RT. Overall, CO dissociation and carbon reoxidation seems an (unavoidable) additional pathway of $\mathrm{CO}$ oxidation on $\mathrm{Co}_{3} \mathrm{O}_{4}$.

The pronounced decline of surface carbonates appearing at higher temperature (at $200-250{ }^{\circ} \mathrm{C}$ the surface of $\mathrm{Co}_{3} \mathrm{O}_{4}$ is almost free of carbonates) suggests that the stable carbonates play a minor role, being rather spectators (3). Decomposition of carbonates to $\mathrm{CO}_{2}$ is, however, facilitated by (excess) $\mathrm{O}_{2}$.

Below $100-150{ }^{\circ} \mathrm{C}$, oxygen vacancies cannot be detected but $\mathrm{Co}_{3} \mathrm{O}_{4}$ exhibits considerable activity. A contribution via a Langmuir-Hinshelwood ( $\mathrm{LH})$ reaction can thus not be excluded. For methane oxidation on cobalt oxide spinel nanocubes Zasada et al. ${ }^{42}$ reported that at $300-450{ }^{\circ} \mathrm{C}$ the $\mathrm{LH}$ mechanism was dominant, whereas above $450^{\circ} \mathrm{C}, \mathrm{LH}$ and MvK coexisted.

The spectroscopically examined possible reaction pathways/ elementary steps of $\mathrm{CO}$ oxidation on $\mathrm{Co}_{3} \mathrm{O}_{4}$ are summarized in Figure 8. Clearly, surface reduction by $\mathrm{CO}$, reoxidation by $\mathrm{O}_{2}$, $\mathrm{CO}$ dissociation/reoxidation presumably at vacancies, and (to a lesser extent) carbonate formation/decomposition are key processes, demonstrating the complexity of the seemingly simple CO oxidation.

\section{CONCLUSIONS}

Combining surface-specific chemical information from operando NAP-XPS and FTIR spectroscopy with activity tests revealed a complex network of four different reaction pathways of $\mathrm{CO}$ oxidation on $\mathrm{Co}_{3} \mathrm{O}_{4}$ : redox Mars-van-Krevelen, $\mathrm{CO}$ dissociation followed by carbon oxidation, formation of carbonate spectators, and possibly Langmuir-Hinshelwood at low temperature (which can currently not be excluded). Experiments performed under steady-state and dynamic conditions were in accordance with a $\mathrm{MvK}$ mechanism above $100{ }^{\circ} \mathrm{C}$, involving the $\mathrm{Co}^{3+} / \mathrm{Co}^{2+}$ redox couple and oxygen vacancy formation. Under steady state, the $\mathrm{Co}_{3} \mathrm{O}_{4}$ surface appeared oxidized and only in pure $\mathrm{CO}$ about $15 \%$ $\mathrm{Co}^{2+}$ species at/near the surface were detected, suggesting the active sites being minority species. CO dissociation followed by carbon reoxidation and carbonate formation/decomposition are additional reaction pathways. Nevertheless, stable carbonates are rather spectators and also $\mathrm{CO}$ dissociation may be a minor route.

This work demonstrates the benefits of combining several operando techniques for studying catalysts under steady state and dynamic conditions, revealing a complex network of reaction pathways. Nevertheless, to assess the relative contributions of all pathways and to determine the rate limiting step, further studies would be required (e.g., by transient/concentration modulation IR spectroscopy ${ }^{43}$ and detailed (micro)kinetic modeling). ${ }^{23-25}$

\section{ASSOCIATED CONTENT}

\section{Supporting Information}

The Supporting Information is available free of charge on the ACS Publications website at DOI: 10.1021/acscatal.8b01237.

$\mathrm{CO}$ conversion at different $\mathrm{CO} / \mathrm{O}_{2}$ ratios, in situ XRD during $\mathrm{CO}$ oxidation, temperature-programmed reduction in $\mathrm{H}_{2}$ followed by XRD, NAP-XPS during $\mathrm{CO}$ oxidation at different (additional) temperatures, MS data and Co $2 \mathrm{p}$ XP spectra obtained in the switching experiments, supplementary FTIR spectra of $\mathrm{CO}$ adsorption and $\mathrm{CO}$ oxidation, FTIR spectra of $\mathrm{CO}_{2}$ adsorption, C 1s spectral fitting parameters, spectral ranges, and assignment of surface carbonates (PDF)

\section{AUTHOR INFORMATION}

\section{Corresponding Authors}

*E-mail: karin.foettinger@tuwien.ac.at (K.F.).

*E-mail: guenther.rupprechter@tuwien.ac.at (G.R.).

ORCID

Karin Föttinger: 0000-0002-2193-0755

Günther Rupprechter: 0000-0002-8040-1677

\section{Present Address}

${ }^{\perp}$ Johnson Matthey, PO Box 1, Belasis Avenue, Billingham, Cleveland, TS23 1LB, U.K.

\section{Author Contributions}

The manuscript was written through contributions of all authors. All authors have given approval to the final version of the manuscript. 


\section{Funding}

This work was supported by the Austrian Science Fund (FWF) in the framework of the Doctoral School "Building Solids for Function ("Solids4Fun") [project W1243] and the ComCat Project [I 1041-N28].

\section{Notes}

The authors declare no competing financial interest.

\section{ACKNOWLEDGMENTS}

We acknowledge the Helmholtz-Zentrum Berlin for synchrotron radiation beamtime at ISISS beamline of BESSY II. The research leading to these results has received funding from the European Community's Seventh Framework Programme (FP7/2007-2013) under grant agreement no. 312284. We are grateful to Dr. Klaudia Hradil and DI Werner Artner for assistance with the in situ XRD measurements. L.L. is grateful to Dr. Leon van de Water from Johnson Matthey for useful discussions.

\section{REFERENCES}

(1) Ertl, G. Reactions at Surfaces: From Atoms to Complexity (Nobel Lecture). Angew. Chem., Int. Ed. 2008, 47, 3524-3535.

(2) Zorn, K.; Giorgio, S.; Halwax, E.; Henry, C. R.; Gronbeck, H.; Rupprechter, G. CO Oxidation on Technological Pd-Al2O3 Catalysts: Oxidation State and Activity. J. Phys. Chem. C 2011, 115, $1103-1111$.

(3) Royer, S.; Duprez, D. Catalytic Oxidation of Carbon Monoxide over Transition Metal Oxides. ChemCatChem 2011, 3, 24-65.

(4) Jia, C.-J.; Schwickardi, M.; Weidenthaler, C.; Schmidt, W.; Korhonen, S.; Weckhuysen, B. M.; Schüth, F. Co3O4-SiO2 Nanocomposite: A Very Active Catalyst for CO Oxidation with Unusual Catalytic Behavior. J. Am. Chem. Soc. 2011, 133, 1127911288 .

(5) Xie, X.; Li, Y.; Liu, Z.-Q.; Haruta, M.; Shen, W. Low-temperature oxidation of $\mathrm{CO}$ catalysed by $\mathrm{Co} 3 \mathrm{O} 4$ nanorods. Nature 2009, 458, 746-749.

(6) Teng, Y.; Kusano, Y.; Azuma, M.; Haruta, M.; Shimakawa, Y. Morphology effects of $\mathrm{Co} 3 \mathrm{O} 4$ nanocrystals catalyzing $\mathrm{CO}$ oxidation in a dry reactant gas stream. Catal. Sci. Technol. 2011, 1, 920-922.

(7) Gu, D.; Jia, C.-J.; Weidenthaler, C.; Bongard, H.-J.; Spliethoff, B.; Schmidt, W.; Schüth, F. Highly Ordered Mesoporous CobaltContaining Oxides: Structure, Catalytic Properties, and Active Sites in Oxidation of Carbon Monoxide. J. Am. Chem. Soc. 2015, 137, 11407-11418.

(8) Iablokov, V.; Barbosa, R.; Pollefeyt, G.; Van Driessche, I.; Chenakin, S.; Kruse, N. Catalytic CO Oxidation over Well-Defined Cobalt Oxide Nanoparticles: Size-Reactivity Correlation. ACS Catal. 2015, 5, 5714-5718.

(9) Ding, K.; Wang, D.; Yang, P.; Hou, P.; Cheng, X. Enhanced CO catalytic oxidation of flower-like $\mathrm{Co3} 4$ composed of small nanoparticles. RSC Adv. 2016, 6, 16208-16214.

(10) Yu, Y.; Takei, T.; Ohashi, H.; He, H.; Zhang, X.; Haruta, M. Pretreatments of $\mathrm{Co} 3 \mathrm{O} 4$ at moderate temperature for $\mathrm{CO}$ oxidation at $-80{ }^{\circ}$ C. J. Catal. 2009, 267, 121-128.

(11) Pollard, M. J.; Weinstock, B. A.; Bitterwolf, T. E.; Griffiths, P. R.; Piers Newbery, A.; Paine Iii, J. B. A mechanistic study of the lowtemperature conversion of carbon monoxide to carbon dioxide over a cobalt oxide catalyst. J. Catal. 2008, 254, 218-225.

(12) Jansson, J. Low-Temperature CO Oxidation over Co3O4/ Al2O3. J. Catal. 2000, 194, 55-60.

(13) Jansson, J.; Skoglundh, M.; Fridell, E.; Thormählen, P. A Mechanistic Study of Low Temperature CO Oxidation over Cobalt Oxide. Top. Catal. 2001, 16, 385-389.

(14) Jansson, J.; Palmqvist, A. E. C.; Fridell, E.; Skoglundh, M.; Österlund, L.; Thormählen, P.; Langer, V. On the Catalytic Activity of Co3O4 in Low-Temperature CO Oxidation. J. Catal. 2002, 211, 387-397.
(15) Perti, D.; Kabel, R. L. Kinetics of CO oxidation over Co3O4/ $\gamma$ Al2O3. Part I: Steady state. AIChE J. 1985, 31, 1420-1426.

(16) Perti, D.; Kabel, R. L. Kinetics of CO oxidation over Co3O4/ $\gamma$ Al2O3. Part II: Reactor dynamics. AIChE J. 1985, 31, 1427-1434.

(17) Perti, D.; Kabel, R. L.; McCarthy, G. J. Kinetics of CO oxidation over Co3O4/ $/$-Al2O3. AIChE J. 1985, 31, 1435-1440.

(18) Broqvist, P.; Panas, I.; Persson, H. A DFT Study on CO Oxidation over Co3O4. J. Catal. 2002, 210, 198-206.

(19) Wang, H.-F.; Kavanagh, R.; Guo, Y.-L.; Guo, Y.; Lu, G.; Hu, P. Origin of extraordinarily high catalytic activity of $\mathrm{Co} 3 \mathrm{O} 4$ and its morphological chemistry for $\mathrm{CO}$ oxidation at low temperature. $J$. Catal. 2012, 296, 110-119.

(20) Pang, X.-Y.; Liu, C.; Li, D.-C.; Lv, C.-Q.; Wang, G.-C. Structure Sensitivity of CO Oxidation on Co3O4: A DFT Study. ChemPhysChem 2013, 14, 204-212.

(21) Jiang, D.-e.; Dai, S. The role of low-coordinate oxygen on Co3O4(110) in catalyticCO oxidation. Phys. Chem. Chem. Phys. 2011, 13, 978-984.

(22) Luo, J.-Y.; Meng, M.; Li, X.; Li, X.-G.; Zha, Y.-Q.; Hu, T.-D.; Xie, Y.-N.; Zhang, J. Mesoporous Co3O4-CeO2 and Pd/Co3O4$\mathrm{CeO} 2$ catalysts: Synthesis, characterization and mechanistic study of their catalytic properties for low-temperature CO oxidation. J. Catal. 2008, 254, 310-324.

(23) Vogel, D.; Spiel, C.; Suchorski, Y.; Trinchero, A.; Schlögl, R.; Grönbeck, H.; Rupprechter, G. Local Catalytic Ignition during CO Oxidation on Low-Index Pt and Pd Surfaces: A Combined PEEM, MS, and DFT Study. Angew. Chem., Int. Ed. 2012, 51, 10041-10044.

(24) Markova, V. K.; Philbin, J. P.; Zhao, W.; Genest, A.; SilvestreAlbero, J.; Rupprechter, G.; Rösch, N. Catalytic Transformations of 1Butene over Palladium. A Combined Experimental and Theoretical Study. ACS Catal. 2018, 8, 5675-5685.

(25) Suchorski, Y.; Datler, M.; Bespalov, I.; Zeininger, J.; StögerPollach, M.; Bernardi, J.; Grönbeck, H.; Rupprechter, G. Visualizing catalyst heterogeneity by a multifrequential oscillating reaction. Nat. Commun. 2018, 9, 600.

(26) Zafeiratos, S.; Dintzer, T.; Teschner, D.; Blume, R.; Hävecker, M.; Knop-Gericke, A.; Schlögl, R. Methanol oxidation over model cobalt catalysts: Influence of the cobalt oxidation state on the reactivity. J. Catal. 2010, 269, 309-317.

(27) Lukashuk, L.; Föttinger, K.; Kolar, E.; Rameshan, C.; Teschner, D.; Hävecker, M.; Knop-Gericke, A.; Yigit, N.; Li, H.; McDermott, E.; Stöger-Pollach, M.; Rupprechter, G. Operando XAS and NAP-XPS studies of preferential $\mathrm{CO}$ oxidation on $\mathrm{Co} 3 \mathrm{O} 4$ and $\mathrm{CeO} 2-\mathrm{Co} 3 \mathrm{O} 4$ catalysts. J. Catal. 2016, 344, 1-15.

(28) Knop-Gericke, A.; Kleimenov, E.; Hävecker, M.; Blume, R.; Teschner, D.; Zafeiratos, S.; Schlögl, R.; Bukhtiyarov, V. I.; Kaichev, V. V.; Prosvirin, I. P.; Nizovskii, A. I.; Bluhm, H.; Barinov, A.; Dudin, P.; Kiskinova, M. X-Ray Photoelectron Spectroscopy for Investigation of Heterogeneous Catalytic Processes. In Advances in Catalysis; Academic Press, 2009; Vol. 52; pp 213-272.

(29) Biesinger, M. C.; Payne, B. P.; Grosvenor, A. P.; Lau, L. W. M.; Gerson, A. R.; Smart, R. S. C. Resolving surface chemical states in XPS analysis of first row transition metals, oxides and hydroxides: $\mathrm{Cr}$, $\mathrm{Mn}, \mathrm{Fe}, \mathrm{Co}$ and Ni. Appl. Surf. Sci. 2011, 257, 2717-2730.

(30) Grosvenor, A. P.; Wik, S. D.; Cavell, R. G.; Mar, A. Examination of the Bonding in Binary Transition-Metal Monophosphides MP $(\mathrm{M}=\mathrm{Cr}, \mathrm{Mn}, \mathrm{Fe}, \mathrm{Co})$ by X-Ray Photoelectron Spectroscopy. Inorg. Chem. 2005, 44, 8988-8998.

(31) Feng, Z. A.; Machala, M. L.; Chueh, W. C. Surface electrochemistry of $\mathrm{CO} 2$ reduction and $\mathrm{CO}$ oxidation on Sm-doped $\mathrm{CeO} 2-\mathrm{x}$ : coupling between $\mathrm{Ce} 3+$ and carbonate adsorbates. Phys. Chem. Chem. Phys. 2015, 17, 12273-12281.

(32) Ferstl, P.; Mehl, S.; Arman, M. A.; Schuler, M.; Toghan, A.; Laszlo, B.; Lykhach, Y.; Brummel, O.; Lundgren, E.; Knudsen, J.; Hammer, L.; Schneider, M. A.; Libuda, J. Adsorption and Activation of CO on Co3O4(111) Thin Films. J. Phys. Chem. C 2015, 119, $16688-16699$.

(33) Shchukarev, A. V.; Korolkov, D. V. XPS Study of group IA carbonates. cent.eur.j.chem. 2004, 2, 347-362. 
(34) Wolfbeisser, A.; Klotzer, B.; Mayr, L.; Rameshan, R.; Zemlyanov, D.; Bernardi, J.; Fottinger, K.; Rupprechter, G. Surface modification processes during methane decomposition on $\mathrm{Cu}$ promoted Ni-ZrO2 catalysts. Catal. Sci. Technol. 2015, 5, 967-978.

(35) Ramsvik, T.; Borg, A.; Kildemo, M.; Raaen, S.; Matsuura, A.; Jaworowski, A. J.; Worren, T.; Leandersson, M. Molecular vibrations in core-ionised $\mathrm{CO}$ adsorbed on $\mathrm{Co}\left(\begin{array}{llll}0 & 0 & 0 & 1\end{array}\right)$ and $\mathrm{Rh}\left(\begin{array}{lll}1 & 0 & 0\end{array}\right)$. Surf. Sci. 2001, 492, 152-160.

(36) Diemant, T.; Bansmann, J.; Behm, R. J. CO oxidation on planar $\mathrm{Au} / \mathrm{TiO} 2$ model catalysts: Deactivation and the influence of water. Vacuum 2009, 84, 193-196.

(37) Denkwitz, Y.; Zhao, Z.; Hörmann, U.; Kaiser, U.; Plzak, V.; Behm, R. J. Stability and deactivation of unconditioned $\mathrm{Au} / \mathrm{TiO} 2$ catalysts during $\mathrm{CO}$ oxidation in a near-stoichiometric and $\mathrm{O} 2$-rich reaction atmosphere. J. Catal. 2007, 251, 363-373.

(38) Köck, E.-M.; Kogler, M.; Bielz, T.; Klötzer, B.; Penner, S. In Situ FT-IR Spectroscopic Study of $\mathrm{CO} 2$ and CO Adsorption on Y2O3, ZrO2, and Yttria-Stabilized ZrO2. J. Phys. Chem. C 2013, 117, 17666-17673.

(39) Davydov, A.: Molecular Spectroscopy of Oxide Catalyst Surfaces; John Wiley \& Sons Ltd: The Atrium, Southern Gate, Chichester, West Sussex PO19 8SQ England, 2003; pp 95-136.

(40) Pokrovski, K.; Jung, K. T.; Bell, A. T. Investigation of CO and $\mathrm{CO} 2$ Adsorption on Tetragonal and Monoclinic Zirconia. Langmuir 2001, 17, 4297-4303.

(41) Fottinger, K.; Schlogl, R.; Rupprechter, G. The mechanism of carbonate formation on Pd-Al2O3 catalysts. Chem. Commun. 2008, $320-322$.

(42) Zasada, F.; Janas, J.; Piskorz, W.; Gorczyńska, M.; Sojka, Z. Total Oxidation of Lean Methane over Cobalt Spinel Nanocubes Controlled by the Self-Adjusted Redox State of the Catalyst: Experimental and Theoretical Account for Interplay between the Langmuir-Hinshelwood and Mars-Van-Krevelen Mechanisms. ACS Catal. 2017, 7, 2853-2867.

(43) Haghofer, A.; Ferri, D.; Föttinger, K.; Rupprechter, G. Who Is Doing the Job? Unraveling the Role of $\mathrm{Ga} 2 \mathrm{O} 3$ in Methanol Steam Reforming on Pd2Ga/Ga2O3. ACS Catal. 2012, 2, 2305-2315. 